\title{
7. Adjusting to democracy: Wissenschaft und Zivilgesellschaft
}

\section{1. „The rounded rational citizen“: der politische Diskurs}

Neue Einsichten, so hat es die Einleitung dieser Untersuchung in Aussicht gestellt, lassen sich in Bezug auf das Verhältnis von wissenschaftlicher Forschung und cultural setting möglicherweise dann gewinnen, wenn die Ergebnisse der vorliegenden Studien zu den englischen Diskussionen über Kriminalitätsgenese und Verbrecherkonstitution (Kap. 2.7., 3.9., 4.8., 5.9., 6.15.) in den Kontext des innenpolitisch wichtigsten Anliegens ihrer Zeit gestellt werden: einem Prozess des adjusting to democracy. ${ }^{1}$ Er beschreibt den Versuch der Anpassung an die Bedingungen einer wachsenden Massendemokratie, die durch den Ausbau des Wahlrechts und die Möglichkeiten politischer Partizipation immer breiterer Bevölkerungsschichten gekennzeichnet war. ${ }^{2}$ Dass die erweiterte Wählerbasis nicht nur den Staat, sondern auch den einzelnen Bürger vor neue Anforderungen stellte, war den Zeitgenossen früh bewusst. „The wide extension of the franchise for both local and central representation", so erklärte Karl Pearson in einer öffentlichen Vorlesung 1892, „has cast a greatly increased responsibility on the individual citizen. " ${ }^{3}$ Hinzu kam, dass in den 1920er, besonders stark aber in den 1930er Jahren demokratische Systeme infolge der Bildung autokratischer und faschistischer Staaten in Ost-, Süd- und Südosteuropa stark unter Druck gerieten, und die innenpolitischen Debatten zusätzlich durch neue außenpolitische Konstellationen an Brisanz gewannen.

Innerhalb dieses Anpassungsprozesses, der übergeordnet für den Erhalt der Demokratie als wesentlich betrachtet wurde, kam der Neubestimmung des politischen Subjektes große Bedeutung zu. Nichts hat in England das Ringen um diese Neubestimmung mehr zum Ausdruck gebracht als die Auseinandersetzung um die Begriffe citizen und citizenship. ${ }^{4}$ Beide Begriffe haben auch innerhalb der Kriminalitätsdebatten, und hier besonders in den Diskussionen über den Strafzweck, eine zentrale Rolle gespielt. Spätestens seit der Jahrhundertwende sprachen Prison Commissioners und Gefängnisreformer diesbezüglich die gleiche Sprache. „It is not to make prisons pleasant, but to construct a system of training such as will fit the prisoner to re-enter the world as a citizen", hieß es im Jahresbericht der

1 Rodney Lowe, Adjusting to Democracy: The Role of the Ministry of Labour in British Politics, 1916-1939, Oxford 1986.

2 Im Untersuchungszeitraum der vorliegenden Arbeit gab es fünf Wahlrechtsreformen: Representation of the People Act von 1832, 1867, 1884, 1918 und 1928.

3 Pearson, Grammar of Science, S. 5.

4 Zur historisch-politischen Entwicklung des Begriffs citizenship in Großbritannien, Frankreich, Deutschland und den USA siehe Andreas FAHrmeIr, Citizenship. The Rise and Fall of a Modern Concept, New Haven und London 2007. 
Prison Commission von 1922/23. ${ }^{5}$ Ein Jahr später erinnerte Ruggles-Brise in seiner Funktion als Vorstand der Internationalen Gefängniskongresse daran, dass keine Anstrengungen gescheut werden dürften, um den Strafgefangenen der Gesellschaft wieder als ,a better and a wiser man and a good citizen “6 zurückzugeben. Auch seine Nachfolger, Maurice Waller und Alexander Paterson, erklärten in ihren Jahresberichten unsentimental und pragmatisch die Wiederherstellung des Straftäters „to ordinary standards of citizenship“ als primäres Ziel des Strafvollzugs, das mit einer „promotion of self-respect“ und der Entwicklung eines „sense of personal responsibility “ verbunden sein müsse. ${ }^{7}$

Gefängnisreformer, die mit Aufmerksamkeit die Berichte der Prison Commission studierten und in ihren Zeitschriften kommentierten, nahmen mit Genugtuung zur Kenntnis, dass sich die Prison Commission immer stärker zu ihrer Pflicht bekannte, „to restore the criminal to civil life. " ${ }^{8}$ Im Verfolgen des individuellen Wohls des Straftäters (Reformierung) sah die Howard League gleichzeitig den größten Schutz für die Gesellschaft, deshalb erinnerte sie die Prison Commissioners beständig daran, „to carry out its duty of protecting society by training offenders as far as possible for citizenship “9. Überhaupt zielte die Arbeit der Gesellschaft nach ihrer Fusionierung 1921 verstärkt darauf ab, „to effect such an alteration in criminal jurisprudence that its basis and purpose shall be to improve the prisoner', not wholly, nor chiefly for the prisoner's sake, but because we hold that no system of treating crime is a safe system unless it aims at protecting the community by reclaiming the offender" 10 .

Selbst so unterschiedliche Reformer wie Havelock Ellis, in jungen Jahren noch Lombrosos Verehrer, und Edward Carpenter, wichtiges Mitglied der Humanitarian League, sprachen sich unisono für die unabdingbare „restoration to society“ und die Wiedereingliederung des Straftäters als „useful citizen“ aus, die durch die Umstrukturierung des Gefängnisses zu einem „industrial asylum“ geleistet werden sollte. ${ }^{11}$ Wenig überraschend waren dann Ende der zwanziger Jahre die For-

${ }^{5}$ Report of the Prison Commission for the Year 1922-1923, hier zit. nach Watson, Prison System, S. 152.

${ }^{6}$ RUgGles-Brise, Prison Reform, S. 193.

${ }^{7}$ Hier zit. nach Fox, English Prisons, S. 70f.; siehe auch den vollen Wortlauf im RePORT OF THE PRISON COMMISSION FOR THE YeAR 1922-1923: „It is not to make prisons pleasant, but to construct a system of training such as will fit the prisoner to re-enter the world as a citizen. To this end the first requisite is greater activity in mind and body, and the creation of habits of sustained industry [...] Next comes the removal of any features of unnecessary degradation in prison life, and the promotion of self-respect; and education on broad lines calculated to arouse some intelligent interests, and to raise the mind out of a sordid circle of selfish broodings. Finally we endeavour to awaken some sense of personal responsibility by the gradual and cautious introduction of methods of limited trust." Hier zit. nach WaTSON, Prison System, S. 152.

8 Siehe den Kommentar zum Bericht der Prison Commission in The Journal of Mental SCIENCE 69 (1923), S. 108.

9 THe HOWARD JOURNAL 1925-1926 (1927), S. 199.

10 The Howard Journal 1 (1921), S. 1.

11 Zu Havelock Ellis siehe The Journal of Mental Science 64 (1918), S. 85; zu Edward CarpenTER siehe ders., Prisons, Police and Punishment. An Inquiry into the Causes and Treatment of 
derung des Schriftstellers Laurence Housman, englische Gefängnisse zum „training ground for citizenship "12 umzugestalten.

Auch in christlich-philanthropischen Kreisen hatte die politische Kategorie des citizen Einzug gehalten. Auch hier ließ sich immer häufiger die Auffassung finden, dass die Erziehung zum Staatsbürger das wirksamste Mittel zum Schutz der Gesellschaft sei: „Society gains nothing from mere punishment“, erklärte Reverend Canon Barnes auf einem Treffen der Penal Reform League 1920 und fuhr fort: „There must be deterrence against crime, granted; but equally we must seek so to strengthen character that if a man is put into prison he emerges with the potentiality of a better citizenship as the result of his term of imprisonment. "13 Obgleich die Terminologie auf den ersten Blick noch an die Rhetorik der evangelikalen Besserungsagenten des 19. Jahrhundert erinnern konnte, hatte sich doch ein entscheidender Bedeutungswandel vollzogen: Nicht mehr die Besserung zu moralisch ,guten Menschen' wurde angestrebt, sondern die in vielerlei Hinsicht nüchternere Herstellung selbständiger und vernünftiger Bürger, das Erzeugen eines „rounded rational citizen“14. Das System der weltlichen Gefängnisbesucher, die keine Bekehrungsgespräche führen, sondern die für den Gefangenen die Verbindung zur Welt draußen herstellen sollten, und die Erwachsenenbildung in den Gefängnissen als eine Art Nachschulung und „re-education of character"15 stellten moderne zivilgesellschaftliche Versuche dar, ein Stück weit an der Herstellung solcher Bürger mitzuwirken (Kap.6.13.).

In der Verlagerung ihrer Zielsetzung von moralischer Besserung zur Staatsbürgerbefähigung lag die eigentliche Säkularisierung der englischen Gefängnisreform. Anders als noch im 19. Jahrhundert, wo es auf staatlicher Seite zunächst darum ging, eine unbekannte Klasse zu identifizieren und deren Verhalten einigermaßen einzuschätzen, trug die Erweiterung der Wählerbasis und der Aufstieg der Labour Party als einer politischen Größe dazu bei, dass sich der staatliche Umgang mit den unteren Klassen (in denen die meisten Straftäter vermutet wurden) nicht mehr auf die bloße Sicherung sozialer Stabilität durch mechanische Wohltätigkeit, auf Verteilungsmodalitäten und die Rationierung materieller Ressourcen oder - im Falle devianten Verhaltens - auf Bestrafung und Separierung

Crime and Criminals, London 1905, S.61-77, hier S.77; ders., England's Ideal and Other Papers on Social Subjects, London 1895, S.1-22; zu Carpenter siehe auch BAILEY, English Prisons, Penal Culture, 1997, S.307: „Edward Carpenter crusaded for a new ideal of social brotherhood and the honest human relation [...] The prisons, Carpenter advised, should be transformed into ,Industrial Asylums' in which prisoners would be educated for citizenship."

12 Laurence Housman, Foreword, in: Archibald Fenner Brockway, New Ways with Crime, S. ix.

13 The Penal Reformer (1920), S.23, Hervorhebung S.F.

14 Mit dem Begriff „rounded rational citizen“ bringt Andrew W. Vincent die Bestrebungen des Geschäftsführers der Charity Organisation Society, Charles S. Loch (siehe CHARLES S. LoCH, Charity Organisation and Social Life, London 1890, S.352), auf einen prägnanten Nenner, Andrew Vincent, Kap. Poverty and Citizenship, in: Vincent und Plant, Philosophy, Politics and Citizenship, S. 101.

15 Field, Psychology of Crime, S. 253. 
beschränkte, sondern die Frage der politischen Integration dieser Schichten zentrale Bedeutung erlangte. „The idea of citizenship“, so formuliert es David Sutton, "could become an organizing principle in a strategy to secure the political incorporation of the subordinate classes. " 16

Wo es darum ging, die Klassengegensätze abzumildern, sollte die Teilhabe an aktiver citizenship mit dem Verweis auf die sozialen und politischen Rechte und Pflichten aller diese Funktion übernehmen. ${ }^{17}$ Auf die Förderung autonomer Staatsbürgerschaft als einem zentralen politischen Bestreben macht auch José Harris in einer Studie über die intellektuellen Rahmenbedingungen britischer Sozialpolitik zwischen 1870 und 1940 aufmerksam: „Their aim as social reformers was not to keep the poor in their place, but to force the poor into active and prudent participatory citizenship. "18 Mit Blick auf die zivilgesellschaftlichen Reformbemühungen lässt sich festhalten, dass sich das Engagement von Bürgern für sozial schwächere Gruppierungen im 19. Jahrhundert zunächst noch im Kontext einer refinement of civic order vollzog (Kap.2.7.), dann aber zunehmend die Gestalt eines adjusting to democracy annahm, eines Versuchs, den unaufhaltsamen Wandel der politischen Verhältnisse durch wachsende Integration der unteren Schichten möglichst gewaltarm, sozialverträglich, aber auch kontrolliert zu gestalten. ${ }^{19}$

Die Stärke und das Selbstbewusstsein der Arbeiterklasse in England haben vermutlich das Ihrige zu diesem Prozess beigetragen. ${ }^{20}$ Anders als in Deutschland,

16 David Sutton, Liberalism, State Collectivism and the Social Relations of Citizenship, in: Mary Langan und Bill Schwarz (Hrsg.), Crises in the British State, 1880-1930, Birmingham 1985, S. 7-32, hier S. 8.

17 Vgl. José Harris, Political Thought and the Welfare State, 1870-1940: An Intellectual Framework for British Social Policy, in: Past and Present 135 (1992), S. 117-39, hier S. 133: „This theme of inculcating citizenship as the ultimate goal of social welfare was omnipresent in the departments of social science and social-scientific associations and journals. "Halliday hat in seiner Arbeit über die Enstehung der englischen Soziologie diese Ausprägung ebenfalls festgestellt: „For the ethical school [of sociology, S.F.] citizenship, conscious social living, was the manifestation of moral awareness and each social worker a proof that individuals could be trained to fulfill their social obligations." J. R. HallidAY, The Sociological Movement, the Sociological Society and the Genesis of Academic Sociology in Britain, in: The Sociological Review 16 (1986), S. 377-398, hier S. 393.

18 Harris, Political Thought, S. 132; ebd. S. 134: „Discussions between social policy-makers and social scientists about the best means of ,stimulating the forces of civic shame and civic pridec (Robert Owen).“

19 Zur Erwartung der sozialen Anpassung an die Ideale der middle classes siehe Ross McKIBBIN, Social Class and social Observation in Edwardian England, in: Transactions of the Royal Historical Society 28 (1978).

20 Generell sollte man den Einwand von F.M.L. Thomson im Gedächtnis behalten, wonach die Durchsetzung bürgerlicher Verhaltensnormen oder Moralvorstellungen mit staatlichen Mitteln in den unteren Schichten in England keineswegs immer unter Zwang oder gegen Widerstände stattgefunden hat. Thomson hat auf das freiwillige Streben der englischen Unterschichten nach bürgerlichen Lebensformen hingewiesen: „The working class did not need to be told that family life was important, that honest toil was better than loafing, or that saving for a rainy day was sensible [...] the working class was eminently capable of generating its own cultural evolution and development in response to aspirations and needs experienced by 
wo sich führende sozialdemokratische Persönlichkeiten aufgrund der eigenen Erfahrung latenter Bedrohung und Ausgrenzung anschickten, sich vom „Lumpenproletariat“ abzugrenzen, für das dann eugenische Maßnahmen durchaus gebilligt wurden, ${ }^{21}$ entwickelten die Mitglieder der Independent Labour Party und der Labour Party ein solches Distinktionsbedürfnis nicht (Kap.4.7.). Im Gegenteil, nicht zuletzt im Kampf gegen die Mittelklasse-orientierte englische Eugenik wuchsen sie zu einer einflussreichen politischen Größe heran. ${ }^{22}$ Auch der gesellschaftliche Umgang mit den Erfahrungen des Ersten Weltkriegs dürften hier eine Rolle gespielt haben. Nicht nur bewährten sich die zum Kriegseinsatz frühzeitig aus der Haft entlassenen Strafgefangenen, ${ }^{23}$ auch der Mut, die Einsatzbereitschaft und die Leidensfähigkeit von Soldaten aus der Arbeiterklasse wurde von den Sozialreformern besonders hervorgehoben. ${ }^{24}$ Der egalitäre Charakter der shellshock-Erkrankung tat ein Übriges (Kap.6.3.). Wer Pflichten für die Gemeinschaft übernommen hatte, so lautete die Forderung der Reformer, der sollte auch in den Genuss staatsbürgerlicher Rechte kommen. Und wer sich durch delinquentes Verhalten aus der Gemeinschaft herauskatapultiert hatte, so zumindest die Einstellung der Howard League for Penal Reform, den galt es unter den Vorzeichen geeigneter Schulung wieder in die Gemeinschaft zurückzuführen. Für ein gregarious animal wie den Menschen, so lehrte es die englische Sozialpsychologie, war diese Rückführung ohnehin der Schlüssel zur eigenen Selbstverwirklichung (Kap. 6.8.).

different groups within it." F.M.L. Thomson, Social Control in Victorian Britain, in: Economic History Review 34 (1981), S. 189-208, hier S. 196; ders., The Rise of Respectable Society. A Social History of Victorian Britain, 1830-1900, London 1988; vgl. auch OBERWITTLER, Von der Strafe, S. 16.

${ }^{21}$ In einem aufschlussreichen Aufsatz zeigt Michael Schwartz, wie sehr die bereits in der Marxistischen Theorie angelegte klare Ausgrenzung des Lumpenproletariats in einem Bericht zu den vorbereitenden Arbeiten zu einem Sterilisationsgesetz zum Tragen kam, das gegen Ende der Weimarer Republik von der sozialdemokratischen Fraktion im Reichstag eingebracht werden sollte. Während für Proletarier Milieu und Struktur als Ursache für kriminelles Verhalten angeführt wurden, schrieben viele Sozialdemokraten dem Lumpenproletariat die Heredität schwerer Kriminalität zu, siehe Michael SCHWARTZ, „Proletarier“ und „Lumpen“. Sozialistische Ursprünge eugenischen Denkens, in: Vierteljahrhefte für Zeitgeschichte 42 (1994), S. 537-570; ders., Kriminalbiologie und Strafrechtsreform. Die „erbkranken Gewohnheitsverbrecher" im Visier der Weimarer Sozialdemokratie, in: Justizministerium des Landes Nordrhein Westfalen (Hrsg.), Kriminalbiologie (Juristische Zeitgeschichte, Bd. 6), Düsseldorf 1997, S. 13-68; für England siehe RADZINOwICZ UND Hood, Emergence of Penal Policy, Kap. 2: The Socialist Interpretation of Crime and its Marxist Connections, S. 34-48, zu Engels Auffassung vom Lumpenproletariat ebd. S. 42.

22 Vgl. John MacNicol, Eugenics and the Campaign for Voluntary Sterilization Between the Wars, in: Social History of Medicine 2 (1989), S. 147-169; ders., The Voluntary Sterilization Campaign in Britain, 1918-1939, in: John C. Fout (Hrsg.), Forbidden History: The State, Society and the Regulation of Sexuality in Modern Europe: Essays from the Journal of the History of Sexuality, Chicago 1992, S. 317-333.

23 Vgl. dazu Evelyn Ruggles-Brise, The Movement of Crime in England and Wales since the London Congress, 1872, up to the present time, together with a suggestion as to a form of International Criminal Statistics for the use of future Congresses, London 1924, S. 1-19, hier S.8, wo der Rückgang der Kriminalitätsraten u. a. auch dem „intense spirit of patriotism pervading all classes“ zugerechnet wird; das Dokument ist vorhanden in TNA, PCOM 7/60.

24 The Penal Reformer (1918), S. 65. 
Zugleich konnte sie als Ausdruck der Wesensbestimmung einer zivilgesellschaftlich organisierten Gemeinschaft gelesen werden, die auf Integration setzte.

Es ist unschwer zu erkennen, dass die Bestimmung des rounded rational citizen sehr genau den Wertvorstellungen der in der Philanthropie engagierten Mittelklasse entsprach. Die Fähigkeit, momentane Wünsche aufschieben und vorausschauend handeln zu können, zählte zu den wichtigsten Eigenschaften, die sich die Mittelklasse als Verdienst zuschrieb und die ihr als notwendige Voraussetzung für politische Partizipation überhaupt galt. Schlagwörter wie „self-governing“, „self-maintaining“ „self-management“ und „economic independence“ verdeutlichen die Richtung, in welche die neue Demokratie erzogen werden sollte. Diese Fähigkeiten verkörperten aber nicht mehr, wie noch im Liberalismus des 19. Jahrhunderts, eine einfache abstrakte politische Idee. Unter dem Einfluss von Individual- und Verhaltenspsychologie wurden diese Fähigkeiten mehr und mehr als das Resultat einer ,rationalen Disposition ${ }^{25}$ aufgefasst, mithin als ein menschliches Vermögen betrachtet, das sich geglückten Anpassungs- und Erziehungsprozessen verdankte (Kap.6.8.). Was die konkreten persönlichen Eigenschaften zukünftiger Staatsbürger betraf, so hatten bereits 1911 die Mitglieder der Penal Reform League diese auf einen einfachen Nenner gebracht: „self-respect, integrity, initiative, energy, technical skill - these are the requirements of successful citizenship. "26

\section{Character}

In der politischen Rhetorik Großbritanniens wurde mit dem Begriff des citizen häufig der Begriff des character verbunden. „The strength of a nation does not lie [...] in the uniformity of its members, but in the variety and strength of the different characters", 27 formulierte es 1906 die in der COS engagierte Helen Bosanquet. Offensichtlich spielte sie dabei sowohl auf das biologische Konzept der Varianz als auch auf die Vorstellung eines leistungsfähigen, rationalen Charakters an. Andrew W. Vincent argumentiert überzeugend, dass die zeitgenössische Berufung auf Charakter zu lange als traditioneller „morally uplifting term“ genommen und dadurch übersehen worden sei, dass seine Bedeutung spätestens nach den unruhigen 1880er Jahren einen Wandel vollzogen habe: „The competitive demands of social life, the capacity for self-restraint and self-reliance were determined by a mature development of character." Mit dem Begriff character sei immer mehr die Vorstellung eines „survival of the most reasonable“ 28 verbunden worden. Auch José Harris schließt sich dieser Ansicht an: „Hence also the emphasis on ,charac-

25 Vgl. dazu Andrew W. Vincent, The Poor Law Reports of 1909 and the Social Theory of the Charity Organization Society, in: Victorian Studies 28 (1984), S. 343-363, hier S. 353.

26 The Penal Reformer (1911), S.6; ebd. S. 5: „Adequate training for those who require it and are capable of becoming useful citizens in free life, either under probationary supervision, or in segregation."

27 Helen Bosanquet (Ehefrau von Bernard Bosanquet), The Family, London 1906, S. 259.

28 Beide Zitate: Vincent und Plant, Philosophy, Politics and Citizenship, S. 101. 
ter, which (however grotesquely misapplied at times in day-to-day social work pratice) was meant to act not as a moral means test, but as a stimulus to independence and political emancipation." 29

Im Kontext der vorliegenden Studie scheint es wichtig festzuhalten, dass die wissenschaftliche Diskussion über die Entwicklung des menschlichen Charakters (als Grundlage menschlichen Verhaltens und Fehlverhaltens) von einem politischen Diskurs über Charakter begleitet wurde. ${ }^{30}$ Vielleicht war deshalb die wissenschaftliche Konzentration auf Charakterforschung gegenüber reiner Intelligenzforschung in den 1920er Jahren, wie weiter unten noch genauer ausgeführt werden soll, keine zufällige. Worauf sich der politische Diskurs über Charakter in Großbritannien verständigt hatte, war die Annahme, dass der künftige Staatsbürger im Grunde mehr Charakter als Intelligenz benötigte. Und die Forschung stimmte dem in gewisser Weise zu. Anders als die angeborene Intelligenz, ein abstraktes Vermögen, bot die Formung des Charakters durch Einwirkung äußerer Einflüsse größeren Spielraum: Da der Charakter ausbaufähig war, bot sich hier der Vorteil, dass sich über ihn die Chancen zur geglückten Anpassung an veränderte Umstände verbessern ließen. „A man is more purposive, more a product of environment, and less limited by heredity, than any other kind of beast" 31 hieß es 1913 in der Sociological Review. Während Intelligenz bestenfalls entdeckt und gefördert werden konnte, ließ sich Charakter trainieren und bilden. Diese Vorstellung beeinflusste auch die Gefängnisarbeit der Prison Commission. In den von Ruggles-Brise eingeführten Jugenderziehungsanstalten, borstals, ging es um ein „habit training to correct the minor faults of character“32. Im Unterschied zu reinen Instinkten war eine erworbene Gewohnheit veränderbar, alte Gewohnheiten konnten aufgebrochen und ,ent-lernt', neue antrainiert werden. ${ }^{33}$ „Education“, so

${ }^{29}$ Harris, Political Thought, S. 141, Hervorhebung S.F.; vgl. auch JANE LewIS, Women and Social Action in Victorian and Edwardian England, Stanford 1991, S. 11: „The language of ,duty together with that of ,feeling ' and of ,character ' was central to the social vocabulary of the late 19th century."

30 Siehe auch Stuart Hall und Bill Schwarz, State and Society, S. 22: „Its concept [new liberalism, S.F.] of citizenship was uncompromisingly constitutional, but principled in its desire to elevate the citizen as a full member of the political nation and the community, as a moral being, with duties as well as rights."

${ }^{31}$ Hugh S. Elliot, The Study of Human Character. A Paper Read Before the Social Psychology Group of the Sociological Society, March 4, 1913, in: The Sociological Review 6 (1913), S. 222-235, hier S. 225.

32 FIELD, Psychology of Crime (II), S. 248; zum Borstal System aus zeitgenössischer Sicht siehe den Beitrag von MARGERY FrY (Geschäftsführerin der Howard League for Penal Reform), The Borstal System, in: Radzinowicz et al. (Hrsg.), Penal Reform in England. Introductory Essays on Some Aspects of English Criminal Policy, London 1940, S. 127-151; auch die Zusammenfassung in LESLIE (Hrsg.), Ruggles-Brise, S. 213-215: „It must be realized that Borstal is never a prison [...] Borstal is an educational training school. Liberty is curtailed more severely than at a Public School.“ (Ebd., S. 214).

${ }^{33} \mathrm{Vgl}$. Thomson, Instinct, Intelligence and Character, S. 16: „A habit is distinguished from an instinct by being acquired, not inborn. In an instinct, there are ready-made nerve connections which ensure that such and such a response will occur in a certain situation. In a habit, the nerve connections have to be made by exercise and satisfaction." 
vor allem die Auffassung von Psychologen, „means redirecting behaviour along new channels. ${ }^{34}$. Auf dieser Grundlage widmete der Prison Commissioner Alexander Paterson dem Ausbau des borstal-Systems in den 1920er und 1930er Jahren große Aufmerksamkeit. ${ }^{35}$

Leonard Hobhouse, Professor für Sozialphilosophie an der LSE und einer der theoretisch anspruchsvollsten Eugenik-Kritiker, ${ }^{36}$ verwies in seinem Buch Liberalism von 1911 auf die Entstehungsbedingungen von character. „[T]o try to form character by coercion is to destroy it in the making. "37 Gerade weil die Herausforderungen einer natürlichen Umwelt und die Reaktionen auf sie für Hobhouse zentrale Faktoren in der menschlichen Entwicklung waren, kam alles darauf an, für dieses freie Wechselspiel die günstigsten Bedingungen zu schaffen. Die Übertragung dieses Gedankens auf die Diskussion über staatliche Strafzwecke fiel 1929 Archibald Fenner Brockway nicht schwer. Er erinnerte nicht nur daran, dass Charakter nicht in einer ,Atmosphäre der Unterdrückung' wachsen könne. ${ }^{38}$ Brockway verwies auf eine noch viel wichtigere Grundvoraussetzung gesellschaftlichen $\mathrm{Zu}$ sammenlebens: Wenn eine Gesellschaft nach dem Charakter derjenigen Individuen beurteilt werde, die sie zusammensetzten, dann müsse der Erziehung und Bildung solcher, Charaktere` oder politischen Subjekte oberste Priorität eingeräumt werden: „Deterrence does not improve character. A community which relies on the method of fear degrades itself. It is the method of terrorism, the weapon of the bully. " 39

Im Kontext der politischen Charakterbildung gewannen pädagogische Fragen auch in der Gefängnisarbeit stark an Bedeutung. „The teacher's ultimate concern is to cultivate“, so betonte der Penal Reformer 1920, „not wealth of muscle, nor fullness of knowledge, nor refinement of feeling, but strength and purity of character." 40 Mehr als einmal thematisierte und kritisierte dieses Journal „our methods of cultivating character.“41 Mit großem Interesse verfolgten Gefängnisreformer deshalb den Besuch Maria Montessoris in England, weil ihnen die Bedeutung einer wissenschaftlichen Pädagogik für ein „training for citizenship“42 bewusst war: „Freedom,

34 Thomson, Instinct, Intelligence, S. 25.

35 Siehe dazu AleXander Paterson, Paterson on Prisons. Being the Collected Papers of Sir Alexander Paterson, hrsg. von S.K. Ruck, London 1951; siehe auch das Kapitel The Borstal System in: Lestie, Ruggles-Brise, S.213-215, darin Paterson: „At the heart of the system is the recognition of the individuality of each lad. They are not the raw recruits of a conscript army, to be arranged neatly in rows according to their physical stature, to be swung rhythmically in a mass across the parade ground to the beat of a drum. Each is a different and a difficult problem.“ (Ebd. S. 214).

$36 \mathrm{Zu}$ Hobhouse siehe Stefan Collini, Liberalism and Sociology. L.T. Hobhouse and Political Argument in England, 1880-1914, Cambridge 1983.

37 Hobhouse, Liberalism (1911), hier zit. nach Stefan Collini, Hobhouse, Bosanquet and the State: Philosophical Idealism and Political Argument in England, 1880-1918, in: Past and Present 72 (1976), S. 86-111, hier S. 96.

38 BrockWAY, New Ways with Crime, S. 21.

39 Ebd.

40 The Penal Reformer (1920), S. 99.

41 The Penal Reformer (1918), S. 24.

42 Hermann Mannheim, The Dilemma of Penal Reform, London 1939, S. 28. 
in Dr. Montessori's view, is not reached by happy-go-lucky-methods, but by scientific study of the needs of the child [...] Dr. Montessori not modified but revolutionised [...] education. “43 Über ihren Besuch in England hieß es schließlich: „Mr. Homer Lane and Dr. Montessori (who has spent the autumn in training English teachers in her well-known methods) are alike in this, from the very earliest years they train children as free citizens, for liberty by liberty. " 44

Während Gefängnisreformer die Möglichkeiten von Strafanstalten als Bildungs- und Schulungsstätten für neue Staatsbürger überschätzen mochten, hielten linksliberale und sozialistische Kräfte stärker an einer Kriminalitätsprävention fest, die vor allem auf die Veränderung sozialer Lebensbedingungen abzielte. Dabei zeigte sich allerdings, dass die Verbesserung der Lebensqualität von einer Verbesserung der Bildungschancen nicht zu trennen war. Auf geradezu exemplarische Weise verband der aus Deutschland emigrierte Hermann Mannheim 1939 in seiner LSE-Vorlesung, die vor allem von zukünftigen Sozialarbeitern besucht wurde, die Fähigkeit zu Gesetzestreue und sozialverträglichem Verhalten nicht nur mit freiheitlichen politischen Verhältnissen, sondern mit der Anhebung von Lebensqualität und Bildungschancen: „To expect from a penal system that it should by itself create law-abiding citizens can only be regarded as a grotesque over-estimation of its powers. Such a spirit of law-abidingness cannot be established by force - it can only be secured by improving the standards of living and of education, and by the setting of a good example." 45

\section{Zum Einfluss der Oxford-Idealisten}

Martin Wiener und David Garland begründen die Medikalisierung des englischen penal complex u. a. mit einem Generationenwechsel im civil service. Für Garland zählen Prison Commissioner wie Sir Evelyn Ruggles-Brise zu jener neuen Beamtengeneration, die sich, die eigene Karriere vor Augen, nüchtern an den Standards naturwissenschaftlicher Effizienz orientiert und sich deshalb gegenüber neuen wissenschaftlichen Erkenntnissen besonders aufgeschlossen gezeigt hätten. Tatsächlich war es Ruggles-Brises' Anliegen, die Prison Commission zu einer effizienten Verwaltungsstelle auszubauen. Richtig ist sicher auch, dass die meisten in Oxford ausgebildeten Beamten, die in der Regel kein naturwissenschaftliches Studium absolviert hatten, mit Hilfe statistischer Erhebungen und der Förderung wissenschaftlicher Projekte in den Gefängnissen der eigenen Arbeit den Anstrich

43 The Penal Reformer (1918), S. 35; zur „pädagogischen Anthropologie“ und Maria Montessori siehe The Penal Reformer (1914), S.6f.; Penal Reformer (1918), S. 25 f.; über ihren Besuch in England und die von ihr angebotenen Trainingskurse siehe The Penal Reformer (1920), S. 22.

44 The Penal Reform League. Quarterly Record 9 (May 1920), S. 22, Hervorhebung im Original; zur pädagogischen Reformbewegung und Homer Lane siehe Kap. 6.13.

45 Mannheim, Dilemma of Penal Reform, S. 19; das Buch ging auf Mannheims Vorlesungen an der London School of Economics im Winterhalbjahr 1938-39 zurück, siehe CARR-SAUNDERS, Vorwort, ebd. S. 8 . 
von Professionalität verleihen wollten. Stärker als in Deutschland musste der civil service in England der Öffentlichkeit Rechenschaft über seine Tätigkeit ablegen. Da Garlands Studie nur die Jahre 1895 bis 1914 umfasst, sind ihm während seiner Recherche die dezidierten Stellungnahmen gegen eugenische Vorstellungen nicht nur von Ruggles-Brise selbst, sondern auch von staatlichen Medizinern wie Horatio Donkin, A.H. Norris oder William Norwood East und sozial engagierten Beamten wie Alexander Paterson oder Charles Russell entgangen (Kap.6.4.). Der Einsatz dieser Männer wurde durch Überzeugungen bestimmt, die sich viel plausibler aus ihrer Biographie und aus bestimmten politischen Einflüssen ihrer Zeit erklären lassen. ${ }^{46}$ Evelyn Ruggles-Brise gehörte zu jener ersten in Oxford ausgebildeten Gruppe von Staatsbeamten, die ganz wesentlich durch die idealistische Philosophie Thomas Hill Greens beeinflusst wurde. ${ }^{47}$ Thomas Hill Green war für ihn „one of the clearest and profoundest thinkers of the end of last century. “48

Green hatte in seiner stark von Kant und Hegel beeinflussten Philosophie die Zusprechung politischer Rechte mit einer wachsenden moralischen Verbesserung aller Bürger und damit des Staates verbunden:

We who were reformers from the beginning always said that the enfranchisement of the people was an end in itself. We said, and we were much derided for saying so, that only citizenship makes the moral man; that only citizenship gives that self respect which is the true basis of respect for others, and without which there is no lasting social order or real morality. ${ }^{49}$

Wenn Sir Godfrey Lushington, Unterstaatssekretär im Innenministerium, vor dem Gefängnis-Untersuchungsausschuss (Gladstone Committee) 1895 das „crushing of self-respect “50 durch den Gefängnisalltag als wesentliches Reformhindernis des Straftäters angeprangerte, ${ }^{51}$ oder die Prison Commission 1924 die Wiederher-

${ }^{46}$ HarRIS, Political Thought, S. 117-39; Harris legt in ihrem Beitrag eine überzeugende Neuinterpretation der Rolle der Oxford-Idealisten im Kontext des entstehenden Wohlfahrtsstaates vor, u. a. durch die Auswertung des International Journal of Ethics, das für viele Jahre das führende Organ einer anglo-amerikanischen „reformist intelligentia“ britischer und amerikanischer Philosophen gewesen sei. Von Mitte der 1890er Jahre bis in die 1930er Jahre hinein wurden in diesem Journal ein kontinuierlicher Strom von Artikeln über die Anwendung der klassischen und modernen idealistischen Philosophie auf zeitgenössische politische, ethische und soziale Wohlfahrt publiziert; zu Thomas Hill Green siehe ders., Lectures on the Principles of Political Obligation. Reprinted from Green's Philosphical Works, Vol. II. With a Preface by Bernard Bosanquet, London 1960 [Reprint einer Ausgabe von 1941]; Die Lectures wurden 1879 von Green in Oxford gehalten, aber erst nach seinem Tod 1882 veröffentlicht. Zum Kreis der Oxford-Idealisten gehörten auch Bernard Bosanquet (z. B. Philosophical Theory of the State, 1899), David George Ritchie (Darwinismus and Politics, 1889; Principles of State Interference, 1891; Darwin and Hegel, 1893; Natural Rights, 1895), Edward Caird, Master von Balliol zwischen 1893-1907 und der Nachfolger Greens als Whyte's Professor of Moral Philosophy, William Wallace, und schließlich auch Arnold Toynbee, Fellow of Balliol von 1878-1883.

${ }^{47}$ Vgl. auch dazu Radzinowisz und Hood, Emergence of Penal Policy, S. 598.

48 Ruggles Brise, Prison Reform, S. 193; siehe dazu auch Bailey, English Prisons, Penal Culture, S. 313 .

49 Thomas Hill Green, hier zit. nach Vicent und Plant, Philosophy, Politics and Citzenship, S. 1, Hervorhebung S.F.; die wichtigsten Passagen für den vorliegenden Kontext befinden sich in GreEn, Lectures, die Paragraphen $\$ \$ 176-206$ (Kap. L.: The Right of the State to Punish).

50 Gladstone Report, S. 8.

${ }^{51}$ Lushington wird auch lobend erwähnt in CARPenter, Prisons, Police and Punishment, S. 18. 
stellung von „self-respect“ des Strafgefangenen als ein wesentliches Ziel der Gefängnisarbeit postulierte, dann offenbarte sich darin, wie weit die Rhetorik der Oxford-Idealisten in politischen und administrativen Zirkeln Fuß gefasst hatte. Die Idealisten, so Vincent und Plant, entwickelten ein neues Staatsverständnis. Dessen Rolle sollte sich nicht mehr auf die Sicherung bloß materieller Wohlfahrt beschränken, sondern seine Interventionen moralisch mit der Verfolgung des „common good“ begründen: „The purpose of the state was to promote the good life of its citizens. " 52

In den vergangenen zwanzig Jahren haben britische Historiker darauf aufmerksam gemacht, dass sich der Einfluss der Oxford-Idealisten nicht auf enge akademischer Zirkel beschränkt habe, sondern dass aus dieser Bewegung eine ganze Reihe konkreter sozialpolitischer Projekte hervorgegangen sei. ${ }^{53}$ Unter dem Einfluss der Idealisten gewann die aktive Sozialarbeit, überhaupt soziales Engagement, an Bedeutung. Besonderes Augenmerk wurde dabei auf solche Institutionen gerichtet, die sich die Integration von Gesellschaftsmitgliedern zur Aufgabe gemacht hatten. In diesem Sinne betonen Vincent und Plant:

A political theory which placed such emphasis upon the moral vocation of citizenship and the value of community organized around a common good could not be indifferent to the activities and agencies whereby individuals are integrated into society and given a sense of membership, whether the agencies be political or located in the sphere of voluntary action and charity. [...] In this sense Idealism had to be a practical creed, giving a sense of moral purpose to efforts, both political and charitable to transform the lives, and not just the material conditions, of the citizens of the modern state. ${ }^{54}$

Das wohl wichtigste und einflussreichste praktische Projekt, das auf diese philosophische Bewegung zurückging, war das university settlement movement. ${ }^{55}$ Die frühesten Gründungen von Sozialzentren setzten im Jahr 1884 in London ein (Aston-Mansfield, Toynbee Hall und Oxford House in Bethnal Green). Diese Zentren boten eine breite Palette von Sozialdiensten an, die von der Bereitstellung von Unterkunft und Verpflegung über die Arbeitsvermittlung bis zum freiwilligem Unterricht (Grundschulwissen und höhere Bildung) durch Mitarbeiter bzw. Studenten der Zentren reichte, die zukünftig im Bildungssektor oder Sozialdienst arbeiten wollten. Der educational psychologist Cyril Burt, der Prison Commissioner Alexander Paterson, Charles Russel und A.H. Norris von der Children's Bran-

52 Vincent und Plant, Philosophy, Politics and Citizenship, S. 2.

53 Vgl. dazu Vincent und Plant, Philosophy, Politics and Citizenship, S. 3; sie beziehen sich u. a. auf die Ergebnisse von Martin Pugh, The Making of Modern British Politics, Oxford 1982, und Kenneth Dyson, The State Tradition in Western Europe, Oxford 1980. Auf die Verbindung zwischen Oxford-Idealismus und der Entwicklung britischer Sozialdemokratie kann in diesem Kontext nicht eingegangen werden, siehe dazu ADAM Ulam, Philosophical Foundations of English Socialism, Havard 1951; vgl. auch SANDrA DEN OTTER, The Search for a ,Social Philosophy': The Idealists of Late Victorian and Edwardian Britain, Oxford Ph.D. 1990.

54 Vicent und Plant, Philosophy, Politics and Citizenship, S. 3 f., Hervorhebung S.F.

55 Zur englischen Settlementbewegung (die amerikanische ist eng mit Jane Adams und der progressiven Ära in Chicago verbunden) siehe SETH Koven, Culture and Poverty. The London Settlement House Movement 1870-1914, London 2009; KATHERINE BENTLEY BEAUMAN, Women and the Settlement Movement, London 1996; John Allen, Unsettling Cities, London 2000. 
ch des Innenministeriums und Alexander Carr-Saunders, Direktor der LSE und ein früher Eugenikkritiker, sie alle waren aktiv in dieser settlement-Bewegung involviert (Kap. 6.4., 6.13.).

Für die Haltung und Stimmung innerhalb der Prison Commission sprach es wiederum, dass sie mit Alexander Paterson in den frühen 1920er Jahren einen Mann aus der aktiven Sozialarbeit berief und nicht - sagen wir - einen Mann wie Karl Pearson, den Typus eines neuen sachlichen Technokraten, der Staatsbeamte durch Naturwissenschaftler ersetzen wollte, weil letztere seiner Auffassung nach einzig in der Lage waren, objektiv urteilen und entscheiden zu können (Kap. 5.9.). Paterson, so hat Victor Bailey in seiner Arbeit über Jugenddelinquenz gezeigt, war es unter anderem zu verdanken, dass sich verunsicherte magistrates und konservative Abgeordnete, die den rasanten Anstieg von Jugenddelinquenz Anfang der dreißiger Jahre mit einer Verschärfung des Strafrechts und des Strafvollzugs beantworten wollten, nicht durchsetzen konnten und statt dessen weiterhin an einem Reformkurs festgehalten wurde. ${ }^{56}$

Mit dem Verweis auf die settlement-Bewegung und auf den Einfluss der idealistischen Philosophie Thomas Hill Greens soll in der vorliegenden Studie nicht der Beweis angetreten werden, alle civil-service-Angestellten seien zu ,Gut-Menschen mutiert. Der Hinweis auf den Einfluss der Oxford-Bewegung dient hier lediglich als Beleg dafür, dass durch die Nähe zum politischen new liberalism, der auf Greens Grundlagen basierte, und durch die persönliche Konfrontation mit konkreten sozialen Problemen die Neigung vieler Beamter erklärt werden kann, die materiellen und sozialen Bedingungen, die menschliches Handeln bestimmten, Milieu und Struktur, nicht aus dem Blick zu verlieren. In vielen Fällen neigten sie einem environmentalism zu, der sich sowohl in vielen wissenschaftliche Konzepten zur Kriminalitätsgenese wiederfinden ließ als auch unter zahlreichen autonomen Sozialreformern anzutreffen war. Für diese Staatsbeamten bedeutete Hills Idealismus ${ }^{57}$ eine säkulare und zugleich moralische Ausrichtung ihrer eigenen Tätigkeit. ${ }^{58}$ Der Staat selbst wurde zu einem moralischen Agenten.

\section{2. "The man in the street": der wissenschaftliche Diskurs}

Welche Rolle aber spielten die verschiedenen Disziplinen, die sich in den Kriminalitätsdiskursen zu Wort meldeten, im Prozess eines adjusting to democracy? Welchen Einfluss hatten ihre Erkenntnisse auf dieses politische Programm? Wenn

56 BAILEY, Delinquency, S. 197-227.

57 Zur Entwicklung der Idealisten und ihren deutschen Wurzeln siehe z. B. RENÉ WELLEK, Immanuel Kant in England, Princeton 1932; Peter RobBins, The British Hegelians 1875-1925, London 1982; kritisch zu Greens Vorstellung eines ,autonomen Subjekts': RYLANCE, Victorian Psychology, S. 315-322.

58 Vgl. Harrison, Philanthropy and the Victorians, S. 237: „T.H. Green's high-minded altruism involved continuity with earlier generations in seriousness, but an increasingly secularized quest for salvation." 
das politische Bestreben der Zeit spätestens mit der dritten Wahlrechtsreform von 1884 tatsächlich in der langfristigen politischen Integration einer wachsenden Wählergemeinschaft lag, Arbeiter und Frauen inklusive, dann war damit die zentrale Frage verbunden, unter welchen Umständen und mit welchen Mitteln sich der rounded rational citizen, herstellen' ließ, welche Voraussetzungen gegeben sein mussten, um einen solchen aktiven, mündigen und verantwortungsbereiten Bürger zu ermöglichen und - negativ gewendet - in welchen Bedingungen die Ursachen für unsoziales und deviantes Verhalten gesucht werden mussten.

Vieles deutet darauf hin, dass dem wissenschaftlichen Wissen die Aufgabe zukam, genau auf diese Fragen eine Antwort zu finden. Es sollte nicht nur darüber aufklären, auf welche Weise die Schaffung eines für die Massendemokratie sozialverträglichen vernünftigen Bürgers möglich war, wie er ,fit' gemacht werden konnte für seine Staatsbürgerschaft, es sollte darüber hinaus vor allem möglichst gründliche Angaben darüber liefern, welche Bedingungen ihn verhinderten und wie in einem solchen Fall ein erfolgreich korrigierendes, staatliches Eingreifen aussehen sollte. Der politisch verhandelte Anpassungsprozess spiegelte sich in der Entwicklung von biologischen, anthropologischen und sozialpsychologischen Anpassungskonzepten in den Wissenschaften wider. ${ }^{59}$ Besonders drei Schwerpunkte in den hier untersuchten britischen Forschungsbereichen sprechen für diesen Zusammenhang: erstens die prominente Stellung des environmentalism in nahezu jedem wissenschaftlichen Ansatz; zweitens die Verschiebung des Forschungsinteresses von reiner Intelligenzforschung zur Entwicklung eines komplexes Konzeptes des menschlichen Charakters, der entwickelt und geschult werden konnte; und schließlich drittens die Entwicklung der englischen Anthropologie zur Sozialpsychologie mit ihrer besonderen Betonung des social instinct unter Beibehaltung der Möglichkeit freier Willensäußerungen, die durch den menschlichen Charakter garantiert werden konnte und den Bürger als rechtsverantwortliches Subjekt aufrechterhielt.

\section{Environmentalism}

Die Statistiker und die Sozialreformer der „Pre-Lombrosian era"60 hatten keinen Zweifel daran, dass sie wirkliches Wissen über Kriminalität und über Kriminelle produzierten und durch ihre akribischen Untersuchungen zur Aufschlüsselung menschlichen Fehlverhaltens beitrugen. Das statistische Verfahren als Werkzeug sozialer Evaluation wurde als großer Fortschritt gefeiert, und es entwickelte sich zunächst ein allgemeines Vertrauen in Zahlen, das, wie es Theodore Porter ausgedrückt hat, eine ,Kultur der Objektivität' begründete. ${ }^{61}$ Dass die eigenen Voran-

59 Vgl. dazu Henry Harris, Mental Deficiency and Maladjustment, in: The British Journal of Medical Psychology (1928), S. 285-315.

${ }^{60}$ Levin und Lindesmith, English Ecology, S. 801.

${ }^{61} \mathrm{Vgl}$. Theodore M. Porter, Statistics, Social Science, and the Culture of Objectivity, in: Österreichische Zeitschrift für Geschichtswissenschaft 7 (1996), S. 177-191. 
nahmen und in vielen Fällen Vorurteile der Statistiker und empirischen Sozialforscher die Ergebnisse beeinflussten, kann nicht bezweifelt werden, aber positivistischen Kriminologen ging es gegen Ende des 19. Jahrhunderts darin nicht anders. Der Übergang zu einer Verwissenschaftlichung der sozialen Lebenswelt kennzeichnete zunächst nichts anderes als das einsetzende Bestreben, Alltagswissen zu quantifizieren und zu systematisieren. Die statistische und empirische Sozialforschung in England wurde aber völlig zu Recht in den 1930er Jahren von amerikanische Soziologen als eine „English Ecology and Criminology"62 wieder entdeckt, denn an das, was Statistiker wie Fletcher, Neison oder Porter, oder auch empirische Sozialforscher wie Mayhew und Booth an relevanten Kriminalitätstheorien entwickelt hatten, ließ sich später soziologisch problemlos anknüpfen (Kap.2).

Schon in diesen frühen Arbeiten wurde, Charakterbildung' im Kontext einer Interaktion zwischen Mensch und Umwelt betrachtet, mit dem Ergebnis, dass religionsbasierte, rein moralisch motivierte Besserungsstrategien an Bedeutung verloren. Durch die Berufung auf wissenschaftliche Untersuchungsmethoden, durch das Bestreben, faktengesättigte Deutungskonzepte vorzulegen, überhaupt durch die systematische Erfassung überindividueller sozialer und ökonomischer Faktoren löste sich die Diskussion über Kriminalität - selbst wenn dies gar nicht beabsichtigt war, weil es primär um die Entwicklung effizienter Reformen ging - aus dem Kontext bloßer moralischer Zuschreibungen und individuellen Versagens. Der Diskurs über Kriminalität versachlichte sich in den Räumen der wissenschaftlichen Auseinandersetzung, auch wenn in anderen Räumen weiterhin eine andere Sprache gesprochen und andere Vorstellungen kultiviert wurden.

Das auf diese Weise produzierte soziale Wissen, das am Milieu- und Strukturgedanken festhielt, wurde durch die Entwicklung anderer Erklärungstheorien, etwa psychiatrischer oder biologischer, nicht überholt oder beseitigt. Unter den Konjunkturen verschiedener Konzepte trat es nur mitunter in den Hintergrund, um dann wieder unter veränderten politischen Bedingungen erneut hervorzutreten. Die Gruppe der Philanthropen und die ihnen nachfolgenden Sozialreformer trugen in besonderem Maße dazu bei, dass dieses Wissen nicht verloren ging. Neue Anknüpfungspunkte ergaben sich besonders über die Erfahrung des Anstiegs der Jugendkriminalität in ökonomischen Krisensituationen wie dem Ersten Weltkrieg und der Weltwirtschaftskrise (Kap.6.4.). Kompatibel erwiesen sich soziologische Theorien darüber hinaus mit politischen Interpretationen, wie sie Archibald Fenner Brockway 1929 auf den Nenner brachte: „Society is the supercriminal. "63 Als anschlussfähig erwiesen sich soziologische Theorien auch an be-

62 Levin und Lindesmith, English Ecology, 801; die beiden amerikanischen Soziologen veröffentlichten im gleichen Jahr einen Artikel über Lombroso, siehe Yale LEvin und ALfREd LiNDESMITH, The Lombrosian Myth in Criminology, in: American Journal of Sociology 42 (1937), S. 653-671.

${ }^{63}$ ArChibald Fenner BrockwaY, A New Way with Crime, London 1928, S. 11; äußerst reizvoll, aber den Rahmen dieser Arbeit sprengend, wäre es, in diesem Kontext die dritte Gruppe englischer Anthropologen zu untersuchen, die Henrika Kuklick als Funktionalisten bezeichnet hat. Diese jüngere Generation britischer Anthropologen, zu denen A.R. Radcliffe-Brown, 
stimmte Entwicklungen in der Psychologie, da es nicht unwahrscheinlich erschien, dass negative äußere Umstände psychischen Stress verursachten, der wiederum zum Auslöser für kriminelles Verhalten werden konnte (modified environmental interpretation).

Als der Reformeugeniker und ehemaliger settlementer Alexander Carr-Saunders 1939 als Direktor der London School of Economics berufen wurde, ${ }^{64}$ hatte sich das Klima in England - ähnlich wie im Roosevelt-Amerika Arthur Finks - für Forschungsprogramme zur Aufklärung von Kriminalität stark zugunsten von soziologischen bzw. sozialstatistischen und psychologischen Untersuchungen verschoben: „We have to bring to bear upon the facts of crime all our ressources of sociological and psychological investigation", 65 erklärte Carr-Saunders 1939 ohne Umschweife in einem Vorwort. Durch eine Konferenz im Home Office angeregt, avancierte Ende der 1930er Jahre die LSE zum Ort eines staatlich finanzierten soziologischen Forschungsprojektes zur Jugendkriminalität, dessen Ergebnisse 1942 vorgestellt wurden. ${ }^{66}$ Aufgrund des Kriegsausbruchs konnte die geplante psychologische Untersuchung jugendlicher Delinquenten nicht mehr durchgeführt werden, doch die statistische Auswertung sozialer Daten - verglichen mit einer Kontrollgruppe - knüpfte an bereits bekannte Konzepte an und führte Faktoren wie „defective familiy relations“, „broken homes“, „parental neglect“ und „outward circumstances" 67 mit große Selbstverständlichkeit auf.

Auch in der englischen Psychiatrie ließ sich eine deutliche Entwicklung in Richtung environmentalism beobachten (Kap. 3). Ärzte wie Henry Maudsley oder David Nicolson haben mit wachsendem Nachdruck auf den Einfluss äußerer Faktoren auf das menschliche Verhalten hingewiesen: „For assuredly the external factors and circumstances count for much in the causation of crime [...] no criminal, to my mind, is really explicable except by a full and exact apprehension of his

Evans Prichard und Bronislav Malinowski gehörten, wurde von der Erfahrung der Weltwirtschaftskrise und dem Aufstieg faschistischer Systeme geprägt. Ihre Theorien erteilten der Ideologie des ökonomischen Individualismus eine klare Absage und glaubten individuelles Verhalten am besten als Produkt eines „social conditioning“ (KUKLICK, Savage within, S. 24) beschreiben zu können. Die Dynamik der individuellen Persönlichkeitsstruktur, für Rivers und Bartlett noch zentraler Bestandteil ihres interaktiven Modells, wurde für die Funktionalisten praktisch irrelevant gegenüber den übermächtigen Operationen sozialer Prozesse.

${ }^{64}$ Biographische Daten zu Alexander Carr-Saunders (1886-1966) können abgerufen werden unter http://library-2.lse.ac.uk/archives/handlists/CarrSaunders/CarrSaunders.html (15.08. 2012); im Archiv der British Library of Political and Economic Science befindet sich eine Sammlung von Carr-Saunders Papieren; zu Carr-Saunders als LSE Direktor von 1937-1957 siehe auch Ralf DaHREndorf, A History of the London School of Economics and Political Science, 1895-1995, Oxford 1995, bes. S. 334-340; S. 394-396.

65 AleXander Carr-Saunders, Vorwort zu Hermann Mannheim, The Dilemma of Penal Reform, London 1939, S.9; Carr-Saunders war bis zu seinem Antritt als Direktor an der LSE Charles Booth Professor of Social Science an der Universität Liverpool.

66 Alexander M. Carr-Saunders und Hermann Mannheim und E.C. Rhodes, Young Offenders. An Enquiry into Juvenile Delinquency, Cambridge 1942; der am Projekt beteiligte E.C. Rhodes war Reader in Statistics.

67 Vgl. CARR-Saunders et al., Young Offenders, Kap. 4: Conclusions, S. 146-159. 
circumstances and nature and of their mutual interaction."68 Die meisten, wenn auch nicht alle Gefängnispsychiater übernahmen damit die Einstellung ihrer Kollegen aus dem öffentlichen Gesundheitsdienst. Auf die Verbesserung sanitärer und hygienischer Bedingungen, auf die ausreichende Nahrungsversorgung von Kindern im schulpflichtigen Alter setzte vor allem die Gruppe der Medical Health Officers. Auch das Royal College of Surgeons lehnte 1903 vor dem Untersuchungsausschuss zur Frage einer möglichen physischen Degeneration britischer Rekruten die Annahme erblich bedingter Degeneration ab. Es handle sich nicht um ,a problem of irreversible decadence, but of environmentally-caused deterioration which could be corrected by better food, cleaner air, less crowded housing, more physical exercise and improved medical care." ${ }^{69}$

Seit Morel (Kap.3) waren Umweltfaktoren vor allem mit negativen Auswirkungen auf die körperliche und geistige Verfassung von Menschen in Verbindung gebracht worden. Erst allmählich, unter dem Einfluss von Präventivmedizin, Pädagogik und educational psychology, emanzipierte sich der Umweltfaktor von den reinen Pathologien, die er angeblich erzeugte. Zunehmend wurde dem Umwelteinfluss jetzt auch eine positive und progressive Rolle zugesprochen. Dies geschah im gleichen Moment, in dem sich in England Psychiater gegen deterministische Verbrecher-Modelle aussprachen. So lehnte David Nicolson in seiner Präsidentenansprache vor der Medico-Psychological Associaton 1895 die Kriminalanthropologie nicht nur ab, weil, wie Neil Davie zu Recht anführt, sie die Arbeit des Psychiaters auf die Vermessung und Klassifizierung von Straftätern beschränkte, sondern weil sie Umstände und Motive des Straftäters nicht angemessen zu erfassen vermochte und damit nichts zur Aufklärung seines Charakters beitrug: „Whatever value we may attach, and rightly attach, to heredity as regards the quality of the brain in individuals, there can be no sort of question as to the value and influence of domestic and social environment, and of education and training, in moulding and forming the character, especially during the more plastic periods of infancy, childhood and youth. "70 Das zukünftige Interesse der englischen Psychiatrie und Psychologie galt dann besonders nach dem Ersten Weltkrieg zunehmend der Charakterbildung, nicht der Verfeinerung von Methoden zur Intelligenzbestimmung.

\section{Charakter versus Intelligenz}

Nicht nur Psychiater wie Nicolson waren davon überzeugt, dass Aussagen über den Charakter eines Menschen bei der Beurteilung seines Verhaltens höher veranschlagt werden müssten als die bloße Bestimmung des Zustandes seines Gehirns.

${ }^{68}$ MAudsley, Criminal Responsibility (1895), S. 663, Hervorhebung S.F.

${ }^{69}$ Royal College of Surgeons, Stellungnahme von 1903, hier zit. nach RiCHARD SOLOWAY, Counting the Degenerates: The Statistics of Race Deterioration in Edwardian England, in: Journal of Contemporary History 17 (1982), S. 137-164, hier S. 143.

${ }^{70}$ Nicolson, Crime, Criminals (1895), S. 581, Hervorhebung S.F. 
Charakter, nicht Intelligenz, war der Schlüssel zum Verhalten eines Menschen, war die Schnittstelle zwischen Außen und Innen, war Produkt ihres Wechselspiels, war das Ergebnis der Lebensgeschichte eines Individuums, war etwas, wie es Thomas Hill Green formuliert hatte, „which has a history in the life of the individual, something that is slowly built up in the course of moral training and under the influence of the social environment."71 Charakter, so die zeitgenössische Annahme, ließ sich herstellen, Intelligenz nicht. Die Wissenschaften lieferten nicht zufällig, so scheint es, Charakter-Modelle, die die Formbarkeit, Erziehbarkeit, Beeinflussbarkeit des Charakters betonten (Kap.6.5.). Die Frage der generellen Abhängigkeit aller geistigen Prozesse von organischen Grundlagen musste dabei nicht berührt werden: „The foundation of character, it is true, rests upon certain innate tendencies“, erklärte 1923 Cyril Burt. Er knüpfte zwar die, inneren Tendenzen' an physiologische Prozesse, bestand aber zugleich darauf: „[C]haracter itself is not innate." 72

Modelle eines flexiblen, bild- und trainierbaren menschlichen Charakters besaßen für die politische Debatte über die Herstellung des rounded rational citizen und die Integration ungeschulter oder nur schlecht geschulter Unterschichten große Relevanz. Die volle Ausübung einer citizenship setzte bestimmte menschliche Vermögen und Fähigkeiten voraus: „Each member of a free community [...] must be capable of citizenship“, hatte James Bryce, Präsident der britischen Sociological Society, während eines Vortrages an der Yale Universität betont und ausgeführt: „Capacity involves three qualities - Intelligence, Self-Control, Conscience, "73 wobei Bewusstsein hier - ganz im Sinne der Terminologie Thomas Hill Greens mit Charakter übersetzt werden konnte. ${ }^{74}$

Ein Kollege von Cyril Burt, der educational psychologist Bernard Thomson, griff dieses Zitat in seinem 1924 erschienen Buch über Instinct, Intelligence and Character auf, um nicht nur an der deterministischen Intelligenzforschung Charles Spearmans Kritik zu üben, sondern an den Stand der Forschung in Bezug auf Intelligenz und Charakter zu erinnern:

Self-control and even conscience seem much more modifiable by the influence of education than is intelligence, even though the latter may not be entirely unchangeable. A certain type of character can almost be guaranteed by a school if it has its pupils long enough, but not a level of intelligence $[\ldots]$ education should look more and more ahead, both in cultivating intelligence and in creating character. For the latter can be created, while intelligence, it would seem, is much more a matter of heredity. [...] [T] he task of the school is rather: [...] Intelligence guidance and character training. ${ }^{75}$

71 Thomas Hill Green, hier in McDougalls Worten wiedergegeben, ders., Social Psychology, S. 329.

72 BuRT, Mental Defect II (1923), S. 170.

${ }^{73}$ JAMES BRYCE, Vortrag an der Yale University, hier zit. nach THOMSON, Instinct, Intelligence and Character, S. 277.

74 „Green tells us that by the true self he means the character of man; he uses also the term ,conscience" to convey the same notion", McDougall, Social Psychology, S. 329, Hervorhebung S.F.

75 ThOMson, Instinct, Intelligence and Character, S. 277, Hervorhebung im Original. 
Der bildbare Charakter war, auch in seiner Funktion als Vermittler zwischen Mensch und Umwelt und als Produkt von Innen und Außen, ${ }^{76}$ für die erfolgreiche Triebunterdrückung entscheidend. Die erfolgreiche Triebunterdrückung wurde mit einer erfolgreichen Sozialanpassung in Verbinung gebracht, von der wiederum eine Abnahme abweichenden und delinquenten Verhaltens erwartet wurde. Wie intelligent ein Individuum war, spielte mit Blick auf seine Integrationsfähigkeit nur eine untergeordnete Rolle. Wichtiger war es, ob dieses Individuum als sozialverträglich eingestuft werden konnte. Darauf machte der Medical Prison Commissioner William Norwood East 1927 in der Diskussion über die Reform des Mental Deficiency Act aufmerksam: „[T] he ultimate criterion of mental deficiency is the capacity for social adaptability and not any more or less conventional standard of educational attainment. "77 Erwies sich ein Individuum als sozialkompetent, dann störte es nicht, wenn es nicht besonders intelligent war. Funktionierte seine soziale Anpassung, dann sollte es in jedem Fall in der Gemeinde belassen werden. Der Gefängnispsychiater East verteidigte hier eindeutig die juristische Konzeption, wonach feeblemindedness oder mental defectiveness als „mental inadequacy for social life" definiert wurde, während sich einige psychologische Konzepte davon unterschieden, in dem sie eher technisch diese mentale Schwäche als „inability to reach a given intellectual standard" bestimmten. ${ }^{78}$

Die bevorzugte Ausrichtung am juristischen Konzept war Ende der 1920er Jahre in England Programm. Sie begründete den allgemeinen Trend zur einer ,EntInstitutionalisierung', die die Betreuung von geistig schwachen oder behinderten Menschen in den Kommunen und durch die Familien vor Ort favorisierte (Kap. 6.3., 6.12.), wie Mathew Thomson es in seiner Arbeit über die Geschichte der mental deficiency gezeigt hat. ${ }^{79}$ Die shell-shock-Erfahrungen und die damit

${ }^{76}$ Vgl. zu dieser Auffassung z. B. Henry Jones, Professor für Moralphilosophie in Glasgow und als Nachfolger Greens einer der führenden Repräsentanten der britischen Idealisten: „[W]hat we call character from one point of view, we call environment from another [...] (A man's) self, or character, and his world have grown together, and [...] they are not merely counterparts of each other, but the same thing looked at in different ways. "HENRY JONES, The Working Faith of the Social Reformer and Other Essays, London 1910, S. 48 und S. 50, Hervorhebung S.F.

77 William Norwood East, Forensic Psychiatry, London 1927, hier zit. nach der Buchbesprechung in The Journal of Mental Science 73 (1927), S. 645, Hervorhebung S.F.

${ }^{78}$ Beide Zitate aus der Besprechung des Buches von S.P. Davies, Social Control of the Mentally Deficient (London 1930) in Mind 40 (1931), S.388-390.

79 Siehe dazu Thomson, Mental Deficiency; ders., Sterilisation, Segregation and Community Care: Ideology and Solutions to the Problems of Mental Deficiency in Inter-War Britain, in: History of Psychiatry 3 (1997), S. 473-498; auch in Bezug auf delinquente Kinder hatte sich das Children and Young Persons Act von 1933 der Argumentation von magistrates, Bewährungshelfern, Mitarbeitern der Children's Branch des britischen Innenministeriums und den Mitgliedern verschiedener Kinderwohlfahrtsverbände angeschlossen und erklärt, eine Institutionalisierung delinquenter Kinder nur als „last resort“ zu betrachten, am effektivsten scheine die „supervision“ durch die eigene Familie, siehe dazu Rose, Psychological Complex, S. 169; bei der Ent-Institutionalisierung spielte sicher auch die finanzielle Entlastung des Staates eine Rolle, siehe dazu MarK JACKSON, The Borderland of Imbecility: Medicine, Society, and the Fabrication of the Feeble Mind in Late Victorian and Edwardian England, Manchester 2000. 
verbundene Schaffung von ambulanten Tageskliniken für psychisch Kranke schuf in der Öffentlichkeit nicht nur größere Toleranz, sondern löste auch in der Psychiatrie selbst ein Umdenken aus (Kap.6.3.). Gerade der gesellschaftliche Umgang mit den Schwächeren galt als Indikator für die Qualität des Gemeinwesens. Stellvertretend für seine Zunft erklärte Henry Harris: „The proportion of subnormals which a society is capable of using in the community might well be considered an index of the quality of that society, and is dependent on its ability to develop a social technique for handling maladjustment. " 80 Der Trend, maladjustment zu korrigieren, um soziale Anpassung zu erreichen, hatte sich in Bezug auf Straftäter durch die Einführung alternativer Strafformen seit 1907/08 abgezeichnet. Dazu zählten die Betreuung durch Bewährungshelfer, der Ausbau spezieller Erziehungsheime für jugendliche Delinquenten (borstals) und selbst noch, wenn auch umstritten, die Sicherungsverwahrung im Reformgefängnis Camp Hill auf der Isle of Wight (Kap. 3.8.). Anders als bei geistig kranken oder defizitären Personen hatte sich bei der großen Mehrzahl der Straftäter - dazu hatten die wissenschaftlichen Diskussionen über Kriminalität und Krankheit und die wachsende Ablehnung ihrer Gleichsetzung beigetragen - nie ernsthaft die Frage gestellt, ob ihr aktive Staatsbürgerschaft und politische Partizipation überhaupt zugetraut werden konnten. Straftäter wurden gerade nicht durch eine medizinische Indikation entmündigt. Im Gegenteil: Ihre Rechtsverantwortlichkeit und Staatsbürgerbefähigung sollten - nicht zuletzt durch Nachschulung und Therapien - befördert werden.

Dass der bloße Mangel an Intelligenz als ausschlaggebendes Kriterium in der Kriminalitätsgenese immer mehr an Bedeutung verlor, verdeutlichten zwei Entwicklungen. Zunächst hätte man erwarten können, dass die Beschäftigung mit den Binet-Simon-Tests die Wertschätzung menschlicher Intelligenz hätte steigern müssen. Tatsächlich war dies aber nicht der Fall. Intelligenztests waren willkommene Hilfsmittel zur Klassifizierung von Schulkindern oder Strafgefangenen, wenn es darum ging, die Zuweisung in bestimmte Schul- oder Gefängnissysteme vorzunehmen. Aber die Feststellung der Intelligenz und ihrer möglichen Defizite allein klärte nicht die Frage sozialer Anpassungsfähigkeit, auf die es gesellschaftspolitisch ankam. Psychologen waren den Nachweis schuldig geblieben, ob tatsächlich erstens ein niedriger Intelligenzquotient „a constant feature of mental inadequacy for social life" darstellte, und zweitens "that the degrees of the IQ correlates uniformerly with the degrees of social incompetence. "81

Ebenso auffällig war, dass es im Zuge der Beschäftigung mit Intelligenztests zu einem deutlichen Herunterkorrigieren der Zahlen geistig defizitärer Straftäter in den Gefängnissen kam, woran selbstverständlich auch die Gefängnisverwaltungen und die Prison Commission ein großes Interesse hatten, um sich gegen den Vorwurf des Gefängnisses als einer psychisch krankmachenden Institution zur Wehr zu setzen. Statt der teilweise vor dem Krieg ins Spiel gebrachten 18 bis 20 Prozent

${ }^{80}$ Harris, Mental Deficiency, S. 312, Hervorhebung S.F.

${ }^{81}$ Hier der kritische Einwand von T.E. Jessop in: Mind 40 (1931), S. 389. 
war nach dem Krieg nur noch von maximal 3 bis 5 Prozent geistig defekter bzw. defizitärer Strafgefangener in englischen Gefängnissen die Rede (Kap. 6.8.). Nichts demonstrierte die ,Ent-Medikalisierung' des Straftäters deutlicher als diese Korrekturen, denn sie bedeuteten, dass von den verbliebenen 95\% und mehr Gefängnisinsassen angenommen werden musste, dass es sich um gewöhnliche, mit durchschnittlicher Intelligenz ausgestattete Menschen handelte. Genau zu diesem Ergebnis kamen dann auch die beiden Gefängnisärzte Hugh A. Griersom und C.H.L. Rixon, die im Gefängnis von Brixton die Intelligenz von Straftätern getestet hatten: „The view that a man who takes to crime is, by that fact, to be adjudged intellectually inferior to the righteous receives no support from these figures. On the contrary they confirm the view generally held by those who have had experience of the criminal, that his intelligence is in no way below that of the ,man in the street.' He is , the man in the street." "82

Wissenschaftler näherten sich durch das Herunterkorrigieren der Zahlen geistig defizitärer Strafgefangener dem politischen Diskurs an, der spätestens seit dem Gladstone Report von 1895 davon ausging, dass es keinen prinzipiellen Unterschied zwischen Kriminellen und normalen Bürgern gab (Kap. 3.8.). Das wissenschaftliche Gewicht nicht ausschließlich auf Intelligenz und damit auf das Fehlen von Intelligenz in Form der viel diskutierten mental deficiency zu legen, bot wissenschaftlich und politisch die Chance, den Straftäter zu ,normalisieren' und damit weiterhin an sein Verhalten Ansprüche und Erwartungen zu richten. Normalisierung meinte hier nicht primär - im Sinne Foucaults - die durch Zwang erreichte (möglicherweise bereits verinnerlichte, d.h. dann freiwillig ausgeführte) Sozialdisziplinierung und Anpassung an eine Norm, die von den Humanwissenschaften vorgegeben wurde, sondern die Schaffung der Möglichkeit, auch Straftätern zugleich Rechte und Verantwortung zusprechen zu können. Gestraft wurde weiterhin nicht aufgrund der Natur des Straftäters, die zu kennen die Humanwissenschaften vorgaben, sondern aufgrund seiner ihm politisch zugesprochenen Freiheit, sich - trotz der Existenz von Instinkten und Emotionen - entscheiden zu können. In der Bestrafung wurde der Täter als ein mit durchschnittlicher Vernunft begabtes und mit verbürgten Rechten ausgestattetes Gesellschaftsmitglied ernst genommen. Dieser Auffassung konsequent verpflichtet ermahnte 1913 deshalb auch der Geschäftsführer der Penal Reform League, Arthur St. John in der Sociological Review: „It is both humiliating and demoralizing for any class of persons to be looked upon as irresponsible." 83 Und rund zwanzig Jahre nach ihm befand auch der inzwischen pensionierte Gefängnispsychiater und Vizepräsident der Howard League, Maurice Hamblin Smith, in seinem Buch über Prisons and $a$ Changing Civilisation, dass die Annahme von Kriminellen als einer distinkten, mit

82 Hugh A. Griersom und C.H.L. Rixon (Medical Officers, H.M. Prison, Brixton), The Intelligence of Criminals, in: The Lancet, 7.August 1926, S. 277, Hervorhebung S.F.

83 Das Zitat stammt aus dem Buch „Citizens Made and Remade: An Interpretation of the Significance and Influence of the George Junior Republic" by William R. George and Lyman Beecher Stowe, London u. a. 1913, S. 169, zit. in der Besprechung von Arthur St. John, in: The Sociological Review 6 (1913), S.277. 
bestimmten negativen Merkmalen und minderer Intelligenz ausgestatteten Klasse viel zu lange eine „misconception“ gewesen sei: „The most striking characteristic of prisoners is the resemblance which they bear to ordinary men and women [...] they are moved by similar motives. They are, in short, just ordinary men and women." 84

Wie ein Diskurs aussehen konnte, der Intelligenz als wesentliches Kriterium von civic worth betrachtete, demonstrierte der Eugenikdiskurs (Kap. 4). Auch der Eugenischen Gesellschaft ging es um die Frage, welche Bürger für die politischen und sozialen Herausforderungen des neuen Zeitalters am besten geeignet waren und welche nicht. Schon Havelock Ellis hatte die zentrale Frage 1890 in seinem an Lombrosos Theorien orientierten Buch The Criminal so formuliert: „We must know what are those stocks that are unlikely to produce the worthy citizen of the furture [...] in an epoch of stress, and of much change and readjustment in the social surroundings and relations of individuals, ill-balanced natures become more frequent, and the anti-social and unlawful instincts are more often called out than in a stagnant society. "85

Das eugenische Bürgerideal, das legten schon Galtons Forschungen nahe, berief sich vor allem auf Intelligenz. Intelligenz war das Schlüsselkriterium in der eugenischen Ideologie von Verdienst. Der Historiker Michael Young hat diese Beziehung auf eine griffige Formel gebracht: „IQ + Effort = Merit“ ${ }^{86}$ Mit Intelligenz aber kam um die Jahrhundertwende ein Kriterium ins Spiel, das viele ausschloss, weil sie - so jedenfalls die zeitgenössische Auffassung - als nicht herstellbar oder beeinflussbar galt. Während das sozialpolitische Programm der Eugeniker aus diesem Grund auf Ausgrenzung, Separierung und Segregation minderbemittelter Individuen setzte, konzentrierten sich die Environmentalisten auf ein „re-attachment of marginal or disaffected groups to the social order. "87 Während Eugeniker versuchten, über Ausgrenzung und Exklusion Kontrolle auszuüben, setzten die Environmentalisten auf Integration in der Hoffnung, dass letztlich alle Gesellschaftsmitglieder zur Sozialverträglichkeit und Selbstkontrolle erzogen werden könnten.

Auch der Civil Service, allen voran die Prison Commission, hat sich auf die Überbewertung menschlicher Intelligenz als Kriterium für sozialpolitische Maßnahmen nicht eingelassen. ${ }^{88}$ Sie hielten sowohl die Kriminalanthropologie Lombrososcher Prägung als auch die heimische Eugenik entschieden auf Distanz. Determinismus und eine Sozialreform, der es um die Herstellung des rounded ratio-

${ }^{84}$ Maurice Hamblin Smith, Prisons and a Changing Civilisation, London 1934, S. viii-ix.

85 Ellis, The Criminal (1890), S. xii und S.371, Hervorhebung S.F.

${ }^{86}$ Michael Young, The Rise of the Meritocracy 1870-1933, London 1961, hier zit. nach RoberT PeEL, Editor's Introduction, in: The Galton Institute (Hrsg.), Essays in the History of Eugenics, London 1998, S. xii.

87 So auch die Einschätzung von Richardson, Love and Eugenics, S. 10, Anm. 33; MacKenzie, Statistical Theory and Social Interest, S. 50.

88 Siehe William Norwood East in The Eugenics Review (1929), S. 172, wo er die Beziehung zwischen Crime and Heredity als nicht überzeugend bezeichnet und sich unter Berufung auf Healy „unimpressed by pedigrees“ zeigt. 
nal citizen ging, schlossen sich im Grunde aus. In seinem 1937 erschienenen Buch Crime and the Community beschrieb der Assistant Prison Commissioner Leo Page das Ankämpfen gegen deterministische Modelle als bewusste Entscheidung der Sozial- und Gefängnisreformer: „It is necessary that the last cruel implications of this theory [Lombroso's, S.F.] should be swept away. So long as traces of it remain so long will the public be inclined to look upon the proposals of prison reformers as the impracticable suggestions of mere visionaries." 89

Dass die englische Eugenik am Ende nichts anderes bedeutete als eine wissenschaftlich eingekleidete Absage an die Verbesserungen von Milieus, haben Wissenschaftler und Sozialisten wie Lancelot Hogben, Professor für Sozialbiologie an der LSE, sarkastisch angemerkt. In seinem 1938 publizierten Buch Science for the Citizen erläuterte er: „Galton's plea for a science of eugenics [...] bore fruit in a movement for obstructing the general enlightenment of mankind. Eugenics became identified with a system of ingenious excuses for combating the amelioration of working-class conditions. "90 Leonard Darwins Werk The Need for Eugenic Reform von 1926 gab Hogben Anlass zu einem weiteren Verdacht: „[T]hat eugenic propaganda has been motivated less by a disinterested concern for the advancement and application of scientific knowledge than by the resentment of a certain section of the privileged class towards the disconcerting results of competition arising out of the extension of educational opportunities. "91 Wachsende Bildung der unteren Schichten, zu der auch Hogbens eigenes Buch beitragen sollte, wurde von Eugenikern eher als Bedrohung im Kampf um begehrte Stellen auf dem Arbeitsmarkt wahrgenommen. Während sie durch die verbesserten Bildungschancen auch in den unteren Schichten den Verlust von Distinktionsmerkmalen befürchteten, setzte Hogben auf die emanzipatorische Kraft von Bildung und sah sich als Wissenschaftler und Bürger dabei in die Pflicht genommen.

\section{Sozialpsychologie und freier Wille}

Kein am Kriminalitätsdiskurs beteiligter britischer Forscher hat die Existenz des Sozialtriebes in Frage gestellt, uneins waren sie sich lediglich über das Ausmaß und die Richtung seiner Funktionen. Das Konzept des social instinct war neben dem biologischen der Variation dasjenige, das am stärksten zur angestrebten Integrationspolitik nach der Jahrhundertwende passte. (Kap. 6.8.) In England erreichte das Konzept möglicherweise eine solche Prominenz, weil es im Grunde ein biologisches Modell für ein politisches Programm bereitstellte: Es unterstrich die Annahme, dass es ein menschliches Anliegen sei, in eine Gemeinschaft integriert $\mathrm{zu}$ werden und um dieser Integration willen auch die Unterdrückung egoistische

${ }^{89}$ Leo Page, Crime and the Community, London 1937, S. 90.

90 Lancelot Hogben, Science for the Citizen. A Self-Educator based on the Social Background of Scientific Discovery (1.Aufl. 1938), London ${ }^{2} 1942$, S. 1054. Das Buch ist Harold Laski gewidmet.

${ }^{91}$ Hogben, Science for the Citizen, S. 1055. 
Triebe in Kauf zu nehmen. Selbst Imperialisten und Nationalisten wie Karl Pearson konnten an den politischen Zusammenhang von ,Stammesbewusstsein' und ,Privatinteressen' vor dem Hintergrund wachsender internationaler Konkurrenz anknüpfen. Bereits 1892 stand für ihn fest, „that the tribal conscience ought for the sake of social welfare to be stronger than private interest, and that the ideal citizen, if he existed, would form a judgement free from personal bias. "92

Doch auch mit den liberalen politischen Vorstellungen eines rounded rational citizen ließen sich die biologischen Bestimmungen eines Sozialinstinktes oder -triebes verbinden. Gedacht wurde dabei an einen Bürger, der durch einen ausgeprägten Sozialinstinkt zur Triebkontrolle fähig war und dadurch die Interessen des Gemeinwohls über die eigenen (Privat-)Interessen zu stellen vermochte. Innerhalb der sozialpsychologischen Debatten über Kriminalität lag es nahe, bei anti-sozialem Verhalten einen defekten, fehlenden oder mangelhaft ausgebildeten Sozialtrieb anzunehmen. Die Problematik, die in kriminellen Handlungen zutage trat, war die offenkundige Unfähigkeit des Täters, sich als Teil einer Gemeinschaft zu begreifen. Spezialisten in den Bereichen der Sozialpsychologie, Psychotherapie und Sozialarbeit betonten immer häufiger diesen Zusammenhang. „Man, then, is a social being [...] and I would suggest that, taken on the whole, there is a tendency for him to adjust himself to the general processes“, erklärte der Psychologe R.G. Gordon, für den Mord und Selbstmord konsequenterweise „a failure in the adjustment of this high level adaptation as a part of a greater whole "93 darstellten.

Bereits Healy (Kap. 6.5.) und Burt (Kap.6.7.) und später Bowlby (Kap. 6.14.) hatten delinquente Jugendliche als oftmals passive, an der Welt und ihren Erscheinungen uninteressierte Wesen beschrieben. ${ }^{94}$ Für die Psychoanalytikerin Alice Raven (Kap.6.9.) waren psychopathische Persönlichkeiten in ähnlicher Weise Menschen mit geringer und stark gestörter Weltbindung und ohne nennenswerte Sozialbeziehungen: „The ,herd' gives them no stimulus, they are detached from social life [...] you may see such persons in the street, walking very fast, looking at no one, often carrying a stick or umbrella."95 Die Attraktivität der sozialen Instinkttheorie von Trotter, Rivers und Tansley (Kap. 6.8.) lag darin, dass sich die Vorstellung von sozial gestörten oder inkompetenten Individuen ohne große Mühe auf politische Vorstellungen übertragen ließ. Für den Schriftsteller und Sozialreformer Laurence Housmann, Pazifist und Mitglied der Howard League, stand fest: „The Criminal is one who suffers from a defective

92 Pearson, Grammar of Science, S. 6, Hervorhebung S.F.

93 Gordon, Certain Personality Problems, S. $61 \mathrm{f}$.

94 Dies war aber nicht mehr mit der „morbid introspection“ der englischen Psychiatrie des 19. Jahrhunderts zu verwechseln, die auf handfeste insanity hindeutete, siehe dazu MICHAEL J. Clark, ,Morbid Introspection', Unsoundness of Mind, and British Psychological Medicine, c. 1830-c. 1900, in: W.F. Bynum et al. (Hrsg.), The Anatomy of Madness. Essays in the History of Psychiatry (The Asylum and Its Psychiatry, Bd.3), London und New York 1988, S. 71-101.

95 Alice Raven, Normal and Abnormal Pschology in Relation to Social Welfare, in: The Sociological Review 21 (1929), S. 125-129. 
sense of citizenship. "96 Der gestörte biologische Sozialinstinkt fand seine Entsprechung in einem defekten politischen ,Bürgersinn‘.

Aber es gab noch eine weitere Auffälligkeit der frühen englischen Sozialpsychologie, die zum politischen Klima außerordentlich gut passte, in der sie entworfen wurde. Psychologische Handlungstheorien, wie sie z. B. der Lehrer von Cyril Burt am University College, William McDougall, entwickelte, ${ }^{97}$ formulierten trotz der Herkunft ihrer Disziplin aus der physiologischen Psychologie und der Verwendung biologischer Instinktmodelle die Möglichkeit freier, autonomer, menschlicher Willensäußerungen. Das besaß nicht nur für die englische Rechtsprechung Relevanz. Offensichtlich beschränkte sich Thomas Hill Greens Einfluss nicht auf die Studenten geisteswissenschaftlicher Fächer in Oxford, sondern erstreckte sich auch auf Mediziner wie William McDougall. Nicht ohne Stolz verwies dieser in seiner äußerst populären Introduction of Social Psychology von 1908 - bis 1950 erschienen 27 Auflagen $^{98}$ - auf die Nähe der von ihm entwickelten Handlungstheorie zur Philosophie Thomas Hill Greens, der autonomen Subjekten die Fähigkeit $\mathrm{zu}$ „true conations or expressions of will“ zusprach. ${ }^{99}$ Thomas Hill Green put forward in very general terms the theory of action which I am defending", 100 betonte McDougall. Green habe nie angenommen, so führte er aus, dass es sich bei moralischem Verhalten oder „volition“, also dem Vermögen oder der Kraft, seinen eigenen Willen einzusetzen, lediglich um „the issue of a conflict of desires“ handle. Scheinbar blinde Impulse, Begierden, Wünsche, Emotionen, die Menschen offensichtlich zu dieser oder jener Handlung nötigten, gehörten zwar konstitutiv zur menschlichen Erfahrung, aber zugleich besaß nach Auffassung McDougalls der Mensch ein Bewusstsein darüber, „that his true self can either oppose such tendencies, or can accept them; and that only when the self thus intervenes to accept or resist desire or impulse do we perform a volitional act." 101

Die Fähigkeit, aus dem Prozess des bloßen Reiz-Reaktion-Schemas herauszutreten, die Entscheidung, ob man Reizen nachgab oder ihnen widerstand, diese Fähigkeit des Menschen hielt McDougall für möglich, wenn auch wesentlich von ihrer „systematic organisation"102 durch Training und Bildung abhängig. Für McDougall bestimmte sich der Charakter eines Menschen folglich durch dessen Fähigkeit, die eigene Handlung als Reaktion auf innere und äußere Impulse selbst bestimmen zu können: moral volition war nichts anderes als „character in

96 Laurence Housmann, Foreword, in: Brockway, New Way with Crime, S. viii; siehe dazu auch die Besprechung des Buches durch Arthur St. John, in der Sociological Review (1929), S. 240, wo erneut von „converting criminals into good citizens" die Rede ist.

97 Zum Einfluss McDougalls auf Cyril Burt siehe Kap. 6.7. und Kap.6.8.

98 Die rasch hintereinander erfolgten Auflagen des Buches sind ein Beleg dafür, wie stark McDougall auch Laien erreicht haben muss; ein Reprint des Buches erschien 1976; zu McDougall (1871-1938) und seinem immensen Einfluss vor dem Zweiten Weltkrieg siehe HeARNSHAW, Short History of British Psychology, S. 185-195, bes. S. 186.

99 Zit. nach McDougall, Social Psychology, S. 329.

100 Ebd., S. 329.

101 Ebd., Hervorhebung S.F.

102 Ebd., S. 330. 
action." ${ }^{103}$ McDougalls Sozialpsychologie stützte also, obgleich in seinen Werken viel von Instinkten und den ihnen korrespondierenden Gefühlen die Rede war, Greens Vorstellung von der Möglichkeit autonomer Subjekte. In seiner Psychologie wurde Instinkten sogar die Aufgabe zugesprochen, der Vernunft zu assistieren. ${ }^{104}$ Nichts anders hatte Wilfred Trotter (Kap. 6.8.) im gleichen Jahr, in dem die erste Auflage der Social Psychology erschien, 1908, in seinem Aufsatz über den herd instinct behauptet. ${ }^{105}$

In England, und dies ist auch für den Kontext der Kriminalitätsdebatten von Bedeutung, hatten Instinkttheorien nicht automatisch deterministische Kriminalitätsdeutungen zur Folge. Sie waren auch nicht generell negativ besetzt oder ließen Reformer ob der Irrationalität des Menschen verzweifeln und bei einigen auf deren Unverbesserlichkeit schließen. Instinkte wurden als notwendig und evolutionär sinnvoll angesehen, aber Menschen waren diesen Instinkten nicht vollkommen ausgeliefert: „This instinct is a universal birthright which human beings share with animals“, hatte bereits 1895 der Gefängnispsychiater David Nicolson in einer Ansprache erklärt, aber auch angefügt:

[I]t would be our natural characteristic through life were it not for the gradual development in us of certain higher and inhibitory intellectual and volitional processes such as prudence, reflection, and a sense of moral duty. These processes go to make up that self-controlling capacity whose function, in the conflict of motives, it is to steer us aright, and to prevent the dominant emotion from exploding or expending itself in some form of crime or vice. ${ }^{106}$

Der Prison Commissioner Sir Evelyn Ruggles-Brise bezog sich wiederum genau auf diese Aussage Nicolsons, als er wenige Jahre später, im Jahr 1900, auf dem Internationalen Gefängniskongress in Brüssel über den professional criminal referierte (Kontext: Sicherungsverwahrung), um deutlich zu machen, dass der Berufsverbrecher seiner Tätigkeit aus freiem Willen, eigener Verantwortung und selbstgewählter Entscheidung nachging. ${ }^{107}$ Während noch vor dem Ersten Weltkrieg zeitgleich in Amerika der Behaviorismus eine ,Psychologie ohne Bewusstsein' hervorbrachte, die unter der Vorherrschaft experimenteller Methoden nur das äußere,

103 Ebd.

104 McDougall war zwar ein „staunch upholder of the instincts“, aber deshalb kein Gegner menschlicher Vernunft, in seinem Konzept assistierten Instinkte der Vernunft („hormic psychology“); den ,Determinismus' des Behaviourismus lehnte er mit der Begründung ab, ,that it implies a denial of creative novelty [...]. Why should we doubt that organic evolution is a creative process and that Mind is the creative agency?" William McDougall, Outline of Psychology, London 1923, S. 497, S. 448) aufschlussreich auch die Besprechung von McDougalls Outline of Psychology (1923) durch Ferdinand C.S. Schiller (Eugeniker), in: Mind 32 (1923), S.496-498, wo der Rezensent McDougalls Ablehnung des Determinismus hervorhebt und ihn für seine „open and courageous challenge to the vogue of mechanistic and atomistic interpretations in psychology“ lobt; auch bei einem Soziologen wie Leonard Hobhouse (Idealist) spielte die Entwicklung „from impulse to will“ eine zentrale Rolle, siehe LeOnard T. Hobhouse, Social Development: its Nature and Conditions, London 1924.

$105 \mathrm{Zu}$ Trotter vgl. Kap. 6.2.

106 Nicolson, Crime, Criminals (1895), S. 577.

107 Siehe den gedruckten Vortrag von RugGLES-BRISE, der u. a. einem Memorandum für das Home Office als Anlage beiliegt (Appendix 3, S. 1-8, hier S. 5), TNA, PCOM 7/286. 
sichtbare menschliche Verhalten zum Ausgangspunkt seines Forschungsprogramms erkor, ${ }^{108}$ war die Preisgabe einer (inneren) menschlichen Willens- und Entscheidungsfreiheit, die auf einem reflexiven Prozess beruhte, der Instinkte und Impulse beherrschen konnte, im England des frühen zwanzigsten Jahrhunderts nicht denkbar, wo es um die Herstellung vernünftiger Bürger ging. ${ }^{109}$

\subsection{Bilanz und Ausblick: „The handmaid, not the mistress of society". Zu den Aushandlungsprozessen zwischen Wissenschaft und Zivilgesellschaft}

Als 1934 Lord Macmillan die 15. Maudsley Lecture zum Thema, The Professional Mind' in der Royal Medico-Psychological Association hielt, stellte er seinem Publikum die rhetorische Frage, auf welche Weise man den Experten am besten „in the public interest"110 gebrauchen (utilize) könne. Die von Macmillan postulierte Verbundenheit von wissenschaftlicher Tätigkeit und öffentlichen Interessen schien für den Sprecher und seine Zuhörer eine ganz selbstverständliche zu sein. Auch die Mitglieder der Howard League for Penal Reform bezogen wissenschaftliche Tätigkeit auf das allgemeine Wohl und definierten die Arbeit des Wissenschaftlers als ein Instrument zur gesellschaftlicher Friedenssicherung, das die Öffentlichkeit über Zusammenhänge (auch ihre eigenen Interessen) aufklären und zugleich Therapieangebote für den Straftäter bereitstellen sollte: „[T]he aim of the man of science is to restore peace to the community, not by punishing the offender, but by helping him to set his muddle straight, and by educating his fel-

108 Der erste grundlegende Aufsatz zum Behaviorismus stammte von JoHN B. WATSON (18781958), Psychology from the Standpoint of a Behaviorist, in: Psychological Review 20 (1913), S. 158-177; einen guten Überblick über die verschiedenen Formen des Behaviorismus gibt Heiner Hastedt, Artikel ,Bewusstsein', in: Ekkehard Martens und Herbert Schnädelbach (Hrsg.), Philosophie. Ein Grundkurs, Bd.2, Reinbek bei Hamburg 1994, S.660-662 (im Kap. Psychoanalyse und Behaviorismus: der psychologische Doppelangriff auf die Zentralstellung des Bewusstseins); vgl. auch John M. O'Donnell, The Origins of Behaviorism: American Psychology, 1870-1920, New York 1985; deutsche Konzepte, die Parallelen zu McDougalls aktivistischer, ,teleologischer' Psychologie aufwiesen, waren Wilhelm Wundts, voluntaristische' Psychologie und Franz Brentanos (Lehrer Husserls), Aktpsychologie‘.

109 Unter dem Blickwinkel der Institutionalisierung der Psychologie hat Mitchell G. Ash argumentiert, dass es gerade die fehlende Institutionalisierung in England gewesen sei, die Alternativen zum Behaviorismus hervorgebracht habe: „In Britian and France, psychology remained, in comparison to Germany and the United States [dort gab es neben den Universitätslehrstühlen auch eine große Anzahl an psychologischen Labors, S.F.], weakly institutionalized from the 1920s to the 1940s. Yet precisely this situation enabled a wide range of theoretical explorations and practical applications, including alternatives to American behaviorism, to flourish", AsH, Psychology, S.263; Ash verweist in diesem Kontext besonders auf die Arbeiten von Cyril Burt und Frederick Bartlett; zur Nähe von Psychologie und education allgemein siehe besonders AdRIAN WoOldRIDGE, Measuring the Mind: Education and Psychology in England, c. 1860-c. 1990, Cambridge 1994.

110 The Right Hon. Lord Macmillan, The Professional Mind. The Fifteenth Maudsley Lecture, in: The Journal of Mental Science 80 (1934), S. 469-481, hier S. 475: „How best to utilize the expert in the public interest." 
low beings to realise that it is to their own interest to assist him rather than to attempt to crush him. "111 Das Journal of Mental Science knüpfte direkt an Greens Terminologie einer political obligation an $^{112}$ und verwies auf das wachsende Wissensbedürfnis der Gesellschaft:

The need for more scientific study of abnormal conduct has long been recognized by psychiatrists. But there is now an increasing demand for guidance on this subject, on the part of magistrates, social workers, teachers, and others. And an obligation is laid upon the specialist to pass on to the community the knowledge which he has acquired by his technical training and his capacity for research. He must [...] present sufficient data to enable the average citizen to understand the value of the services which the specialist is capable of rendering to the community. ${ }^{113}$

In dem Moment, in dem der Wissenschaftler seiner Aufklärungsverpflichtung gegenüber der Gesellschaft nachkam, eröffnete sich ihm die Möglichkeit, diese Gesellschaft von der Wichtigkeit seiner Tätigkeit zu überzeugen und dabei eigene Anerkennung zu finden. Voraussetzung dafür aber war, dass Wissenschaft und Gesellschaft den wechselseitigen Dialog suchten.

Experten in England haben mit einer offensichtlich großen Selbstverständlichkeit ihre Rolle als Dienstleister für die Gemeinschaft, ihre „consulting capacity“,114 akzeptiert. Für Gefängnispsychiater wie Maurice Hamblin Smith schien es 1926 eine Selbstverständlichkeit zu sein, dass Wissenschaften wie die Psychologie stets nur „the handmaid and not the mistress of society“ sein könnten: „It is, ultimately, for society to decide in what way it will deal with its problems. " 115 Mit diesem Bekenntnis erinnerte Smith nicht nur an die nach unterschiedlichen Regeln funktionierenden Bereiche von Politik, Wissenschaft und Rechtsprechung, deren Autonomie es zu respektieren galt, er gab besonders seiner Überzeugung Ausdruck, dass es stets der Gesellschaft überlassen bleiben müsse zu entscheiden, auf welche Weise sie ihre Probleme und Konflikte lösen und im Prozess der Klärung von den Deutungsangeboten der Wissenschaften Gebrauch machen wolle. Ein solcher Hinweis ließ sich freilich nur dann mit einer gewissen Selbstverständlichkeit formulieren, wenn es durch die Gegebenheiten des cultural setting begründete Hoffnung gab, dass die Aushandlungsprozesse, in denen die Kompatibilität oder auch Nichtkompatibilität wissenschaftlicher Deutungsangebote mit den vorherrschenden Wertesystemen überprüft wurden, auch tatsächlich im Sinne einer Bemühung um das Auffinden eines allgemeinen gesellschaftlichen Wohls geführt wurden, kurz gesagt: Wenn man Vertrauen in das Funktionieren der Aushandlungsverfahren selbst haben konnte.

Ohne Frage wurde die wissenschaftliche Forschung über Kriminalität und Täterkonstitution in England, wie in anderen Ländern auch, in einem nicht un-

111 The Howard Journal (1928), S. 207.

112 Siehe GreEn, Lectures on the Principles of Political Obligation (1882).

113 Besprechung des Buches von Irving J. Sands und Phyllis Blanchard, Abnormal Behaviour, London 1923, in The Journal of Mental SCIence (1924), S. 139, Hervorhebung S.F.

114 Macmillan, Professional Mind, S. 476.

115 Beide Zitate: Maurice Hamblin Smith, Psycho-analysis and Its Development. A Discussion Held at the Annual Meeting of the Royal Medico-Psychological Association in London on July 15, 1926, in: The Journal of Mental Science 72 (1926), S. 557. 
erheblichen Maße von den sich ändernden gesellschaftlichen Interessenslagen bestimmt. Darin muss aber kein Nachteil für die Wissenschaft liegen. Lancelot Hogben meinte sogar beobachten zu können, dass Wissenschaft immer dann auffällige Fortschritte verzeichne, „when men and women are actively engaged in rational endeavour to change their social environment." Neue soziale Umstände, so seine Begründung, trügen dazu bei, das Interesse sowohl auf neue Probleme als auch auf neue Aspekte alter Probleme zu lenken. ${ }^{116}$ Diejenigen, die etwas verändern wollten - im englischen Kontext waren dies im Untersuchungszeitraum vor allem Philanthropen, Sozialreformer und fortschrittliche Verwaltungsbeamte -, trugen allerdings nicht nur die Erwartung an die Wissenschaften heran, von ihnen hilfreiche Deutungsangebote zu erhalten, über deren Annahme oder Ablehnung dann öffentlich diskutiert und entschieden werden sollte. Zum Vertrauen in die Aushandlungsprozesse gehörte auch die eigene Bereitschaft zu akzeptieren, dass in diesen Aushandlungsprozessen nicht nur die wissenschaftlichen Inhalte zur Disposition standen, sondern im Prozess der Überprüfung ihrer Kompatibilität mit gesellschaftlichen Normen, Werten oder Erwartungen zugleich auch diese Normen selbst überprüft, bestätigt, modifiziert, revidiert oder ersetzt werden konnten.

So haben sich langfristig in den englischen Kriminalitätsdebatten nicht nur die wissenschaftlichen Erklärungsmodelle für die Ursachen von kriminellem Verhalten und Täterkonstitution verändert, verfeinert, differenziert, auch eine Verschiebung des gesellschaftlich verhandelten Strafzwecks ließ sich dabei beobachten. Aus den primär moralisch orientierten Besserungsstrategien für sündige Seelen wurde die nüchternere Strategie der Anpassung an die kommende Massendemokratie, mithin die Strategie der Herstellung rationaler Bürger, die mit bestimmten Kompetenzen ausgestattet sein mussten. 1939 thematisierte Alexander CarrSaunders genau diese dynamische Verkopplung von Kriminalitätsforschung und Strafzweckdiskussion: „We have to bring to bear upon the facts of crime all our resources of sociological and psychological investigation. In the second place we have to attain some clarity in our ideas regarding the social responsibility of normal citizens towards those who offend, and regarding the concepts of guilt, punishment and reformation." ${ }^{117}$ Am Ende, so lässt sich behaupten, sollte aus den Aushandlungsprozessen ein Orientierungswissen hervorgehen, das als Ergebnis einer Abwägung der unterschiedlichen Elemente des Diskussionszusammenhangs verstanden werden kann. Dieses Wissen musste aber stets offen bleiben für eine Debatte darüber, was in der Gesellschaft zu einem gegebenen Zeitpunkt als normal gelten sollte bzw. auf welchen Begriff von Normalität sie sich jeweils verständigen wollte.

Positivistische Kriminalanthropologie italienischer Provenienz und heimische Eugenik haben es im Untersuchungszeitraum nicht vermocht, die Grundannahmen englischer Rechtsstaatlichkeit zu erschüttern. Nicht nur die englische Justiz,

116 Vgl. Hogben, Science for the Citizen, S. 1057.

117 Alexander Morris Carr-Saunders, Vorwort zu Hermann Mannheim, The Dilemma of Penal Reform, London 1939, S.9. 
die sich selten bis gar nicht in die Grundlagendiskussionen eingemischte, war nicht bereit, auf das mit Rechten und Pflichten ausgestattete zurechnungsfähige Subjekt zu verzichten. Auch Prison Commissioners, Regierungsbeamte und Verwaltungsangestellte haben an der klassischen Auffassung von Schuld- und Straffähigkeit und angemessener Vergeltung des Strafaktes bei aller Anerkennung wissenschaftlicher Ergebnisse festgehalten. ${ }^{118}$ Inspiriert von einer idealistischen Philosophie, die die moralische Besserung der Bürger an die Zusicherung politischer Rechte und damit an die Möglichkeit politischer Partizipation knüpfte, gewann gerade in der Auseinandersetzung mit der Kriminalanthropologie die Strategie eines adjusting to democracy an Profil. Die Rückführung des Straftäters als kompetenten Bürger und nützliches Mitglied in die Gesellschaft blieb auch in philanthropischen und sozialreformerischen Bemühungen das erklärte Ziel. Auch wenn die Wirklichkeit nicht annähernd an dieses erstrebte Ziel heranreichte, so führte doch die Ausrichtung auf dieses Ziel dazu, dass wissenschaftliche Kriminalitätskonzepte, die dieses Vorhaben in Frage stellten oder sogar - bezogen auf bestimmte Gruppen von Straftätern - als unmöglich erklärten, mehrheitlich konsequent zurückgewiesen wurden.

Zeitgleich wurden in den englischen Wissenschaften alternative Erklärungsmodelle entwickelt, die die Strategie der Herstellung kompetenter Bürger flankieren und unterstützen konnten. Es lässt sich nicht im Sinne eines chronologischen Vorher/Nachher entscheiden, ob sich dabei die Wissenschaften dem politischen Diskurs anschmiegten oder ob ihre Konzepte die Richtung des politischen Diskurses letztlich bestimmten. Was sich aber zeigen lässt und in dieser Arbeit versucht wurde, ist das starke Aufeinander-Bezogensein von Wissenschaft und Gesellschaft, das zum einen die Wirkmächtigkeit des cultural setting bestätigt, von der die Produktion wissenschaftlichen Wissens nicht getrennt werden kann, zum anderen aber auch auf das Funktionieren von Aushandlungsprozessen in einer Zivilgesellschaft verweist, die Wissenschaft nicht blind rezipierte, sondern sich selbst zutraute, Wissenschaft beurteilen und einordnen zu können. Was diese Zivilgesellschaft auszeichnete, war ein starkes Interesse an Expertise, bei einer gleichzeitig klaren Zurückweisung von ,Expertokratie؛. Was aber die besonderen Kommunikationsstile der Aushandlungsprozesse zwischen Wissenschaft und Zivilgesellschaft betrifft, so lässt sich über sie vielleicht vorerst nur sagen, was Lord Macmillan im Kontext seiner Rede mit Blick auf die Rechtsprechung zu bedenken gab: „The faculty of practical judgment is not always to be found in conjunction with scientific learning. The art of judgment is itself an art." 119

118 Geradezu klassisch dazu 1932 die Stellungnahme des Departmental Committee on Persistent Offenders, das nach 39 Sitzungen und der Anhörung von 66 Zeugen in seinem Abschlussbericht erklärte: „We do not agree with the view that crime is a disease, or that it is generally the result of mental disorder. [...] And further, if we accept the psychological explanation in certain cases of crime, we do not regard it necessary as an excuse for the offence." Report of the Departmental Committee on Persistent Ofenders, Parliamentary Papers (1932), Cmd. 4090, S. 46.

119 Macmillian, The Professional Mind, S. 476, Hervorhebung S.F. 
